Canadian Science Publishing

Canadian Journal of Earth Sciences Revue canadienne des sciences de la Terre

\title{
U-Pb Zircon Geochronology and Depositional History of the Montresor group, Rae Province, Nunavut, Canada
}

\begin{tabular}{|r|l|}
\hline Journal: & Canadian Journal of Earth Sciences \\
\hline Manuscript ID & cjes-2016-0170.R1 \\
\hline Danuscript Type: & Article \\
\hline Complete List of Authors: & $\begin{array}{l}\text { Percival, John A.; Geological Survey of Canada } \\
\text { Davis, William J.; Geological Survey of Canada, } \\
\text { Hamilton, Michael A.; University of Toronto, Department of Earth Sciences }\end{array}$ \\
\hline Keyword: & $\begin{array}{l}\text { U-Pb geochronology, zircon, Paleoproterozoic, Rae cover sequence, } \\
\text { Depositional constraints }\end{array}$ \\
\hline \multicolumn{2}{|c}{} \\
\hline
\end{tabular}

\section{SCHOLARONE"}

Manuscripts 


\title{
U-Pb Zircon Geochronology and Depositional History of the Montresor group, Rae Province, Nunavut, Canada
}

\author{
John A. Percival (corresponding author john.percival@canada.ca; 613-995-4723) \\ Geological Survey of Canada, 601 Booth St. Ottawa, ON K1A 0E8 \\ William J. Davis (bill.davis@canada.ca) \\ Geological Survey of Canada, 601 Booth St. Ottawa, ON K1A 0E8 \\ and \\ Michael A. Hamilton (mahamilton@es.utoronto.ca) \\ Jack Satterly Geochronology Laboratory \\ Department of Earth Sciences \\ University of Toronto \\ 22 Russell St., Toronto \\ Ontario, Canada M5S 3B1
}


J.A. Percival, W.J. Davis and M.A. Hamilton: U-Pb Zircon Geochronology and Depositional History of the Montresor group, Rae Province, Nunavut, Canada

\begin{abstract}
Paleoproterozoic metasedimentary successions of the northwestern Canadian Shield provide records of tectonic events, but definition of depositional ages has proved elusive.

Previously little studied, the Montresor belt of western Nunavut yields new insight on the 2.2-1.8 Ga time window. Based on U-Pb analyses of detrital zircon in sedimentary rocks and igneous zircon in sills, arenite of the lower Montresor group was deposited between 2.194 and $2.045 \mathrm{Ga}$, and arkose of the upper Montresor group after $1.924 \mathrm{Ga}$, adding constraints on the Rae cover sequence. The lower Montresor arenite yielded an older $(3.05-2.58 \mathrm{Ga})$, and a younger, more tightly constrained group $(2.194 \pm 0.014 \mathrm{Ga})$. Four of six zircon grains analysed from a gabbro sill within the lower Montresor have discordant ${ }^{207} \mathrm{~Pb} /{ }^{206} \mathrm{~Pb}$ ages $(2.71,2.66,2.53,2.39 \mathrm{Ga})$ and are considered to be inherited, whereas two grains provide an age of $2045 \pm 13 \mathrm{Ma}$, interpreted to date crystallization and providing a minimum age for the lower Montresor package. Upper Montresor arkose contains detrital zircon with probability density peaks at 2.55-2.25 Ga and 2.1$1.92 \mathrm{Ga}$, along with scattered older grains (3.8-2.65 Ga). The youngest grain yields an age of $1924 \pm 6$ Ma, establishing a maximum age for sandstone deposition. Provenance is inferred to
\end{abstract} have been from the west, where igneous sources of 2.5-2.3 Ga (Queen Maud block) and 2.03$1.89 \mathrm{Ga}$ (Thelon orogen) are known. Collectively, the new ages suggest a minimum 120 m.y. gap between deposition of the pre-2045 \pm 13 Ma lower and post-1924 \pm 6 Ma upper parts of the Montresor group. Similar age constraints may apply to other parts of the Rae cover sequence.

Keywords: U-Pb geochronology; zircon; Paleoproterozoic; Rae cover sequence; Depositional $\underline{\text { constraints }}$ 


\section{Introduction}

Unlike most Archean cratons, the Rae Province of northern Canada (Fig. 1) was tectonothermally reworked during the ca. 2.35 Ga Arrowsmith and ca. 1.9-1.8 Ga Trans-Hudson orogenies (Berman et al. 2005; Berman 2010; Berman et al. 2013a; Pehrsson et al. 2013a,b), as well as being influenced by the ca. $2.0 \mathrm{Ga}$ Thelon orogeny. The sporadically preserved Paleoproterozoic Rae cover sequence (Rainbird et al. 2010) serves both as a record of basin evolution during break-up of the Rae Province, and as a monitor of subsequent tectonism (Pehrsson et al. 2013a; Percival and Tschirhart, submitted).

Based on lithostratigraphic correlations and detrital zircon age constraints, the Rae cover sequence, comprising the Amer, Ketyet River, Montresor and Chantrey groups (Rainbird et al. 2010), appears to be part of a broad, intracontinental sedimentary system including the Piling and Penrhyn groups of the northeastern Rae (Morgan et al. 1975; Corrigan et al. 2009; St-Onge et al. 2009; Wodicka et al. 2014; Partin et al. 2014), and scattered basins of the southwestern Rae (Bethune et al. 2010; Ashton et al. 2013; van Breemen et al. 2013). In their sedimentary strata, the intracratonic facies record much of the Rae Province's Paleoproterozoic history, from rift and subsidence, to the influx of orogenic detritus, and in their post-depositional tectonic history, the effects of subsequent collision and mountain building. The modest metamorphic grade of the clastic sequences makes them attractive targets for studies of provenance and age determinations through detrital zircon geochronology. However, past efforts to date the quartz-rich units near the base of the sequence have yielded only Archean detritus, thus providing only loose constraints $(2.5-1.9 \mathrm{Ga})$ on ages of sedimentary deposition. In this study, we explore the sedimentary record of the Montresor belt (Frisch and Patterson 1983), complementing the growing knowledge base for the Rae cover sequence (Rainbird et al. 2010; Partin et al. 2014; Ferderber et al. 2013). 


\section{Regional Geological Setting}

The Rae Province extends from beneath Phanerozoic cover in Saskatchewan and Alberta through mainland Nunavut, NWT and central Baffin Island, to west-central Greenland (Fig. 1). Dominated by Meso-to Neoarchean plutonic rocks, it contains older vestiges and the widespread ca. 2.6 Ga Snow Island granitic suite (Peterson et al. 2010; 2015; Hinchey et al. 2011). These rocks were sporadically reworked during the ca. 2.35 Ga Arrowsmith orogeny (Berman et al. 2005; 2013a). The Rae cover sequence was deposited after the Arrowsmith event and prior to ca. $1.90 \mathrm{Ga}$ (Rainbird et al. 2010). Only remnants of the cover sequence are preserved in the elongate, northeast-trending Ketyet River, Amer, Montresor and Chantrey belts in central Nunavut, as a result of deformation and metamorphism during the 1.9-1.8 Ga Trans-Hudson orogeny, followed by regional exhumation and erosion (Fig. 2).

To the west, the Rae Province is separated from the 4.0-2.5 Ga Slave craton by the ca. 2.0-1.9 Ga Taltson-Thelon orogen (Hoffman 1989; Berman et al. 2015b). It is bordered to the southeast by the Hearne Province and intervening ca. 1.9 Ga Snowbird tectonic zone (Hoffman, 1989; Berman et al. 2007; Martel et al. 2008).

A composite stratigraphic framework for the Rae cover sequence has been developed by Rainbird et al. (2010), based primarily on the Amer belt and tentative correlations with adjacent outliers. Despite complex folding and thrusting (Patterson 1986; Calhoun et al. 2014; Jefferson et al. 2015), primary stratigraphic relationships are preserved within the Amer belt, where four stratigraphic assemblages are recognized. Assemblage 1 has a locally preserved basal regolith, overlain by sandstone, conglomerate and a distinctive thick, white orthoquartzite unit. These rocks generally contain detrital zircon of only Archean age (3.0-2.6 Ga; Rainbird et al. 2010). Assemblage 2 consists mainly of quartz arenite and some dolostone and is distinguished from 
Assemblage 1 by the presence of mafic volcanic flows and/or gabbroic sills. Detrital zircons from the correlated Quartzite Ridge provide a maximum depositional age of ca. $2.5 \mathrm{Ga}$ (op cit.). Owing to the absence of zircon of Paleoproterozoic age, the depositional age of assemblages 1 and 2 is poorly constrained but considered to be 2.3-2.1 Ga. Assemblage 3 contains fine-grained marine clastic units and bedded to stromatolitic carbonate. Its base is an unconformity in the Ketyet River belt (op cit.). Detrital zircon populations include earliest Proterozoic (2.52-2.48 Ga) and younger (1.95-1.91 Ga) grains, providing a maximum depositional age. Assemblage 4 has a coarse basal conglomerate containing clasts from lower in the section, and has been interpreted as syntectonic molasse and flysch (Zaleski et al. 2000). The youngest detrital zircons provide a maximum depositional age of ca. $1.90 \mathrm{Ga}$ (Rainbird et al. 2010).

\section{Geology of the Montresor belt}

Two main age groups are represented in the region (Figs. 3, 4): Archean (ca. 2.6 Ga) granite and orthogneiss with sparse paragneiss and amphibolite enclaves; and Paleoproterozoic units including metasedimentary rocks of the Montresor belt (Heywood 1961; Frisch and Patterson 1983; Frisch 1992; 2000) and minor plutonic rocks. Archean granitoid units range in composition from tonalite to granodiorite and granite (Frisch 2000). A K-feldspar porphyritic granodiorite from north of the Montresor belt yielded a U-Pb zircon age of $2589 \pm 3 \mathrm{Ma}$ (Fig. 3; Davis et al. 2014). Within the region these rocks range texturally from homogeneous and weakly foliated to augen gneissic, layered gneissic or mylonitic. They are generally metamorphosed to amphibolite facies, except south of the Amer mylonite zone, where some rocks attained granulite facies (Fig. 1; Fraser 1988; Tella 1994; Berman 2010), dated locally at ca. $1.82 \mathrm{Ga}$ (U-Pb monazite; Berman 2010). At the regional scale, deformation and metamorphism of the Archean rocks is attributed to effects of both the ca. 2.35 Ga Arrowsmith and ca. 1.9-1.8 Ga Trans- 
Hudson orogenies (Berman et al. 2005; Berman 2010; Berman et al. 2013a; Sanborn-Barrie et al. 2014).

The Archean units are have traditionally been considered to be depositional basement to the Montresor group, although no unconformity has been observed (Frisch and Patterson 1983; Frisch 2000). Recent results (Percival et al. 2015a) support a more complex relationship among the Archean and Paleoproterozoic units (Fig. 4), including elements of the fold-thrust belt interpretation established in the Amer belt, $50 \mathrm{~km}$ to the south (Patterson 1986; Rainbird et al. 2010; Tschirhart et al. 2013; Pehrsson et al. 2013a; Calhoun et al. 2014).

The northeastern end of the Montresor belt consists of a structural footwall complex made up of imbricated units including: augen gneiss, quartz arenite and related arkose, chert, dolostone and related calc-silicate rocks, as well as micaceous schist and wacke, the latter unit intruded by boudinaged sills of gabbro and foliated granodiorite. Assemblages in calc-silicate units including forsterite-diopside-tremolite indicate metamorphism to mid-amphibolite facies. All units are transected by sparse dykes up to $\sim 10 \mathrm{~m}$ wide, of hornblende granodiorite, biotite granite and pegmatite. Contacts between augen gneiss and sedimentary units are characterized by deformation corridors of flaggy foliation, penetrative lineation, grain size reduction and obliteration of primary textures, and are interpreted as $\mathrm{D}_{1}$ fault zones (Figs. 3, 4; Percival et al. 2015a,b). No conglomerate or other evidence of an unconformity has been observed at these contacts. Map patterns of units and fault zones suggest polyphase structural imbrication of gneisses and sedimentary units. The metasedimentary rocks of the footwall complex are collectively referred to as the lower Montresor group (Percival et al. 2015b). Lithologically, these units resemble regionally extensive quartzite, mudstone and dolostone strata exposed in the 
lower parts of the Amer and Ketyet River belts (Rainbird et al. 2010), informally known as Ps1 and Ps2 (Paleoproterozoic sedimentary assemblages 1 and 2; Pehrsson et al. 2013a).

At structurally higher levels, in the core of the Montresor syncline, are weakly deformed and metamorphosed, fine-grained arkosic sandstone, siltstone and calcareous sedimentary units informally referred to as the upper Montresor group. These units correspond to assemblage 3 (Ps3) of the Amer and Ketyet River belts (Rainbird et al. 2010; Pehrsson et al. 2013a).

At the boundary between the footwall complex and overlying upper Montresor units near the southwestern end of the belt, the footwall complex consists of muscovite-andalusitesillimanite-garnet schist indicating middle-amphibolite facies conditions $\left(3.3 \mathrm{kbar}, 575^{\circ} \mathrm{C}\right)$ at 1861-1844 Ma (Berman et al. 2015a; Dziawa 2016). The schistosity dips moderately northwest and is concordant with well-preserved bedding in the structurally overlying, weakly deformed sandstone, siltstone and minor carbonate units of the upper Montresor group. Metamorphic assemblages in these fine-grained metasedimentary units include muscovite-biotite and epidotezoisite-clinozoisite-actinolite, defining middle greenschist-facies conditions, dated locally by metamorphic monazite at $1847 \pm 15$ Ma (Percival et al. 2015b). The interface between the upper and lower parts of the Montresor group is interpreted as a late- to post-metamorphic, low-angle extensional detachment fault $\left(\mathrm{D}_{2}\right)$ with vertical offset of several kilometres, to account for the missing upper greenschist- and lower amphibolite-facies rocks.

The base of the lower Montresor group is exposed in the southwestern part of the belt as a ductile high-strain zone separating amphibolite-facies schist from gneissic to mylonitic granitoid rocks. Although the age of the high-strain zone relative to other generations of structures is poorly constrained, metamorphic monazite yielded a broadly syn-metamorphic U- 
$\mathrm{Pb}$ age of $1850 \pm 5 \mathrm{Ma}$, and the event is interpreted as $\mathrm{D}_{3}$ in the deformation chronology (Percival et al. 2015b).

Sedimentary units of the upper Montresor group include fine-grained, thinly laminated sandstone and siltstone, with sparse dolostone and calcareous sandstone. The siliciclastic units include laterally continuous beds with heavy mineral bands containing detrital magnetite, tourmaline, zircon and apatite that form prominent magnetic marker units. Aeromagnetic maps outline a pair of doubly-plunging, open, upright $\mathrm{D}_{4}$ synclines (Tschirhart et al. 2015). Detailed analysis reveals low-angle layer truncations interpreted as $\mathrm{D}_{1}$ thrusts (Tschirhart and Percival 2016; Percival and Tschirhart submitted). In the southwestern syncline, a prominent aeromagnetic low corresponds to a stratabound unit of altered, brecciated igneous rocks that can be extrapolated aeromagnetically for at least $50 \mathrm{~km}$ (Tschirhart et al. 2015).

\section{U-Pb Geochronology}

Analytical methods are described in Appendix 1 and results reported in Tables 1 and 2. The GSC SHRIMP (Sensitive High-Resolution Ion MicroProbe) was used for detrital zircon U-Pb analyses, wheras for gabbroic zircon, $\mathrm{U}-\mathrm{Pb}$ analyses were conducted by ID-TIMS at the Jack Satterly Geochronology Lab at the University of Toronto. Isoplot version 3.00 (Ludwig 2003) was used to generate concordia plots and calculate weighted means. All error ellipses on the concordia diagrams and the weighted mean errors are reported at $2 \sigma$. Probability density diagrams were generated using AgeDisplay (Sircombe 2004).

A range of options exists for determining the maximum depositional ages of sedimentary rock units based on detrital zircon populations (e.g. Dickinson and Gehrels 2009). In this paper, our approach is guided by the distribution of relatively concordant ages in the detrital 
populations. Hence, in one rock (sample 1), the maximum age is based on a cluster of statistically overlapping ages on zircons with similar compositional characteristics, whereas in another (sample 4), the age is based on multiple analytical spots on the youngest grain of a broad age spectrum.

\section{Age constraints on deposition of the Montresor group}

\section{Quartz Arenite, lower Montresor group (sample 1 (14PBA-029; 11289))}

This sample was taken from a ca. $1 \mathrm{~km}$-wide, fault-bounded panel of homogeneous quartzite surrounded by gneissic granodiorite, constituting part of the putative basement unit of Frisch $(1992 ; 2000)($ Sample 1, Fig. 4). The rock is a massive, medium-grained, white to pale pink, sub-arkosic arenite (Fig. 5a; Pettijohn et al. 1987) comprising 90\% quartz, $8 \%$ feldspar, $1 \%$ biotite, $1 \%$ muscovite and trace amounts of apatite, titanite and zircon. Zircons are 50 to $150 \mu \mathrm{m}$ in maximum length, moderately to well rounded, and colourless to pale brown (Fig. 6). Most grains are fractured and many are metamict. Back scattered secondary electron (BSE) images of polished grains generally reveal growth zoning consistent with igneous crystallization.

The detrital zircon population (Fig. 7; Table 1) includes Mesoarchean (3.05-2.80 Ga) and Neoarchean (2.77-2.58 Ga) populations, with a few older grains (3.6-3.2 Ga). The largest peak on the probability density distribution plot (Fig. 7) is made up of 33 grains with ages centred on $2.19 \mathrm{Ga}$. These grains have uniformly low uranium concentrations (28-132 ppm U) relatively high $\mathrm{Th} / \mathrm{U}(0.7-1.1)$, and may represent a single age source at $2194 \pm 14 \mathrm{Ma}$. However, owing to relatively low lead contents there is significant analytical uncertainty, and a range of ages cannot be ruled out. Nevertheless, the 2.19 Ga cluster defines the maximum depositional age for the rock.

Granodiorite Sill, lower Montresor group (sample 2 (14PBA-027D; 11291)) 
Two samples were taken from rare boudinaged sills within a ca. 400-m-wide, faultbounded panel of interlayered wacke, mudstone and dolostone (Samples 2, 3, Fig. 4). The panel is structurally underlain by granodiorite gneiss and overlain by massive white quartzite (Fig. 4). A sill of foliated granodiorite (14-PBA-027D; Z-11291; Fig. 5b; Table 1) is dominated by zircon with ca. $2.6 \mathrm{Ga}$ ages, presumed to be inherited, but also includes a small population of Paleoproterozoic zircon with an age of $1849 \pm 9 \mathrm{Ma}$. The latter have high uranium contents, $\mathrm{Th} / \mathrm{U}$ ratios typical of igneous zircon, and could represent the crystallization age of the sill. The Neoarchean zircons are discordant with $\mathrm{Pb}$-loss dominantly along a discordia line with a lower intercept defined by the ca. $1.85 \mathrm{Ga}$ zircon age (Fig. 8). This age imposes a lower limit on the age of sedimentation for the lower Montresor group.

\section{Pegmatitic Gabbro Sill, lower Montresor group (sample 3 (12PBAB-017E))}

A second sample was collected from a pod of coarse gabbro, part of a bedding-parallel string of boudins (Fig. 5c). The sample yielded a small population of dominantly short, colourless or pale yellow-brown zircon prisms of variably quality, some of which are sharply terminated and some that are more rounded (suggesting a possible mixed magmatic and xenocrystic population)(Fig. 9). A subordinate population of irregular and anhedral grains is also present. Six of the best quality, short, clear, colourless, prismatic zircons were selected for analysis (Fig. 9). Data for four 2-3:1 prisms - sharply faceted to euhedral with only slight rounding, yield model ${ }^{207} \mathrm{~Pb} /{ }^{206} \mathrm{~Pb}$ ages of $2708 \pm 2 \mathrm{Ma}(\mathrm{Z1} ; 2.6 \%$ discordant; Table 2$), 2659 \pm 6$ Ma (Z3; 4.4\% discordant), $2534 \pm 8 \mathrm{Ma}(Z 4 ; 8.5 \%$ discordant) and $2387 \pm 7 \mathrm{Ma}(\mathrm{Z} 6 ; 13.8 \%$ discordant), shown graphically in figure 10a. These older grains are characterized by relatively low $\mathrm{U}$ concentrations (66-97 $\mathrm{ppm})$ and variable $\mathrm{Th} / \mathrm{U}(0.2-0.9)$. A fifth, sharply faceted, short, 
clear, colourless, low-U prism $(\mathrm{Z} 2)$ yields a model ${ }^{207} \mathrm{~Pb} /{ }^{206} \mathrm{~Pb}$ age of $2047 \pm 16 \mathrm{Ma}$ and is essentially concordant, while a sixth grain (Z5) is about $3 \%$ discordant, with a ${ }^{207} \mathrm{~Pb} /{ }^{206} \mathrm{~Pb}$ age of $2040 \pm 27 \mathrm{Ma}$ (Fig. 10b). Both analyses show very low U levels (30-60 ppm), low total Pb (4-5 pg), and similar $\mathrm{Th} / \mathrm{U}(0.58,0.59)$. Free regression of the two latter analyses, whose ${ }^{207} \mathrm{~Pb} /{ }^{206} \mathrm{~Pb}$ ages overlap at the $2 \sigma$ level of uncertainty, yields a lower intercept within error of the origin (Fig. 10b). Assuming zero-aged Pb-loss in these fractions yields a weighted average, or upper intercept age of $2045 \pm 13(\mathrm{MSWD}=0.2$; probability of fit $=64 \%)$. Considering that the sill intrudes a sedimentary sequence, it is probable that the older zircon population is xenocrystic in origin. We consider the sharply faceted $2045 \pm 13$ Ma zircon population to have crystallized directly from the gabbroic magma, providing a robust estimate of the age of magmatic crystallization, and a minimum age for deposition of the lower Montresor host sedimentary unit.

\section{Fine-grained sandstone, upper Montresor group (sample 4 (12PBAB-19A; 11290))}

A sample of thinly-bedded, pink sandstone (Fig. 5d) was collected from within the magnetic marker sequences of the central Montresor belt (sample 4, Fig. 4). These pink, grey and green, thin-to thickly cross-bedded sandstones and siltstones dip gently to moderately south. Sparse metamorphic muscovite visible in thin section marks the only discernable foliation. Heavy minerals, including magnetite, tourmaline, apatite and zircon are concentrated in mmscale bands (Fig. 11).

Detrital zircon grains are generally moderately rounded and prismatic, ranging from colourless to altered, turbid and darkly coloured (Fig. 12). They have relatively high uranium contents and many are discordant (Table 1). Age clusters are present at 2.55-2.25 Ga (18 of 59 grains) and 2.1-1.92 Ga (39 grains; Fig. 13). Older individual grains (3.8-2.65 Ga) round out the detrital population. Of the six youngest zircons, one concordant grain (Table 1, grain 9) yields a 
weighted mean $(\mathrm{n}=4$; MSWD $=1.2$; probability $=0.31)$ age of $1923.8 \pm 5.9 \mathrm{Ma}$, taken as the maximum depositional age of the rock.

\section{Discussion}

\section{Provenance}

Based on lithological similarities, the lower Montresor group has been correlated with the lower parts of the Amer and Ketyet River groups (Figs. 1, 14), specifically assemblages 1 and 2 (Rainbird et al. 2010). Detrital zircon populations from the basal quartz arenite units of these sections contain exclusively Archean grains (Rainbird et al. 2010; Ferderber et al. 2014). The equivalent white quartz arenite unit of the lower Montresor group was not sampled in this study. However, the Archean zircon population of the sub-arkosic arenite, with a broad range of ages between 3.05 and $2.60 \mathrm{Ga}$, resembles those of the Ayagaq formation of the Amer belt, the lowermost unit of the Ketyet River group (Rainbird et al. 2010), and the Lower Dewar Lakes formation of the Piling Group (Fig. 1; Wodicka et al. 2014), reflecting the diverse basement ages of the Rae Province. The Montresor sample differs significantly as it includes a prominent age peak at $2.19 \mathrm{Ga}$. Although this age is absent from the lower quartz-rich members of the Rae cover sequence, it is sparsely represented in younger rocks of the sequence, notably the upper Penrhyn (Fig. 1) and Karrat groups (Partin et al. 2014). Detritus of this age is abundant in the upper part of the Murmac Bay group in northern Saskatchewan (Fig. 1; $2171 \pm 31$ Ma youngest detrital grain; Ashton et al. 2013) and sparse in the Thluicho Lake group (Bethune et al. 2010), $900 \mathrm{~km}$ to the southwest, where no source has been identified. In the Piling Group, $1200 \mathrm{~km}$ to the east, upper Dewar Lakes quartzite contains two 2160 Ma grains and this age is considered to mark the onset of passive margin development and rifting by ca. $1980 \mathrm{Ma}$ (Wodicka et al. 2014). A similar interpretation could apply to the lower Montresor group, whereby 2190 Ma would 
represent initiation of subsidence (cf. Rainbird et al. 2010). The source of 2190 Ma detritus is unknown within the Rae Province (e.g. Ashton et al. 2013), although the volume of material in the Montresor sample ( $>40 \%$ of the zircon population) could indicate a proximal provenance. Magmatic rocks of 2190 Ma age are present regionally, in the form of the east-trending MacQuoid dyke swarm $300 \mathrm{~km}$ to the southeast and correlative Tulemalu dykes of the Chesterfield block, near the Rae- Hearne Province boundary (Fig. 1; Tella et al. 2001; Buchan and Ernst 2013). Pehrsson et al. (2002) noted the geochemical similarity of these dykes to tholeiitic flows characteristic of assemblage 2 in the Ketyet River belt. We speculate that the dykes and flows could have been part of a bimodal magmatic suite whose felsic component has now been eroded and incorporated into the Montresor group.

Sandstones of the upper Montresor group have been correlated lithologically with assemblage 3 of the Rae cover sequence (Rainbird et al. 2010), and the detrital zircon population supports the correlation (Fig. 14). In addition to Archean grains (3.8-2.65 Ga), Paleoproterozoic zircon clusters of 2.5-2.3 and 2.1-1.92 Ga (Fig. 11) likely represent contributions from the Arrowsmith and Thelon orogens respectively. This age spectrum, common in assemblage 3 of the Rae cover sequence, is generally attributed to derivation of sediments from the west, where sources include Paleo- to Mesoarchean gneisses (Davis et al. 2013; 2014) and 2.5-2.3 Ga plutonic rocks of the Queen Maud block (Schultz et al. 2007; Tersmette 2012; Davis et al. 2014) and Taltson basement complex (McNicoll et al. 2000), as well as 2.03-1.89 Ga plutonic and metamorphic rocks of the Thelon orogen (van Breemen et al. 1987; Bostock and van Breemen 1994; McDonough et al. 2000; Davis et al. 2014; Berman et al. 2015b).

\section{Age Constraints}


The depositional age of the basal quartz-rich units of the Rae cover sequence remains poorly constrained owing to the absence of Proterozoic detrital zircon. These rocks are generally considered to have been deposited in the 2.3-2.1 Ga age range (Rainbird et al. 2010), following the 2.5-2.3 Ga Arrowsmith orogeny. Mafic flows in assemblage 2 of the Amer belt are geochemically correlated with gabbro dated at $2153 \mathrm{Ma}$ (LeCheminant and Roddick, unpublished, cited in Hadlari et al. 2004; Jefferson et al. 2015). At face value, the new geochronological data for the lower Montresor group strongly support this inference, by constraining deposition between $2194 \pm 14 \mathrm{Ma}$ and $2045 \pm 13 \mathrm{Ma}$, however some uncertainty is imposed by local stratigraphic disruption by $\mathrm{D}_{1}$ faults. The age bracket interpretation requires that the sub-arkosic arenite and wacke-mudstone-dolostone sedimentary units be part of the same stratigraphic assemblage, despite being structurally disrupted (Fig. 4). This interpretation is supported by the common association of quartzite-carbonate-wacke-mudstone in assemblage 2 of the Amer and Ketyet River belts (Rainbird et al. 2010). Based on the lithological similarities, we infer that the dated lower Montresor units belong to assemblage 2 (Fig. 14).

Mafic magmatism in the 2030 -2060 Ma age range is sparse but known from widespread locations in the Rae Province. Anorthositic rocks of the deep-crustal Penylan domain (Fig. 1) have ages of $2046 \pm 18,2048 \pm 22$, and $2032 \pm 5 \mathrm{Ma}$ (Davis et al. 2015). Gabbroic anorthosite from Southampton Island is $2058 \pm 4$ (Rayner et al. 2013).

While the new age data help constrain the timing of deposition of the lower Montresor group and by inference, the older parts of the Rae cover sequence, they raise questions about the topographic expression of the Arrowsmith orogen. Berman et al. (2013a) summarized pressuretemperature-time information for Arrowsmith orogenic events across the Rae Province, illustrating widespread thermal and tectonic effects. Continental arc plutonic rocks were 
emplaced in the eastern Queen Maud block between ca. 2.55 and $2.32 \mathrm{Ga}$, followed by a collisional event ca. $2.35-2.30 \mathrm{Ga}$, which is sporadically preserved across a 2500 by $400 \mathrm{~km}$ region representing the basement on which the Rae cover sequence was deposited. The Arrowsmith magmatism, collisional tectonism and amphibolite-to granulite-facies metamorphism should have produced mountainous topography at $2.3 \mathrm{Ga}$, yet the quartz-rich rocks of the basal Rae cover sequence are interpreted to reflect "a protracted period of enhanced chemical weathering on a slowly subsiding, stable craton" (Rainbird et al. 2010),. In particular, why are 2.45-2.30 Ga igneous rocks of the Queen Maud block (Schultz et al. 2007; Tersmette 2012; Davis et al. 2013; 2014), which are exposed less than $200 \mathrm{~km}$ northwest of the Montresor belt, not represented in the detrital zircon population? It seems unlikely that all topographic expression of the Arrowsmith orogeny was removed by 2045 Ma, considering that Arrowsmithaged detritus $(2.5-2.23 \mathrm{Ga})$ is abundant in the younger (ca. $1.9 \mathrm{Ga})$ sedimentary assemblages $(3$ and 4) of the Rae cover sequence, suggesting that units of Arrowsmith age were being eroded significantly at that time. Alternatively, it is conceivable that rocks of Arrowsmith age were not exhumed until ca. 1.9 Ga. Davis et al. (2014) reported U-Pb zircon evidence of a widespread thermotectonic event in the Thelon zone and Queen Maud block between ca. 1.93 and 1.90, and Berman et al. (2013b) described a number of areas where deep-crustal rocks with Arrowsmith high-grade metamorphic imprints also record metamorphism of Trans-Hudson age (1.90-1.83 Ga). This observation permits a scenario in which the Arrowsmith orogeny resulted in only minor crustal thickening, exhumation and erosion, such that deep-crustal units were not exposed until Thelon or Trans-Hudson time. Resolution of this question may lie in ongoing thermochronological studies aimed at defining the exhumation history of the Rae Province (D. Regis, pers. comm. 2016). 
The sample of upper Montresor sandstone provides a maximum depositional age of $1923.8 \pm 5.9$ Ma. This sequence has been correlated on lithological grounds with assemblage 3 of the Amer and Ketyet River belts (Rainbird et al. 2010), and the spectrum of detrital zircon ages corresponds well (Fig. 14). The maximum depositional age may be close to the rock's actual age of deposition, based on the observations that: a) younger magmatic rocks are present in the Thelon orogen, at 1.91, 1.90, 1.89 Ga (Berman et al. 2015b) but are not present in the detrital population; and b) clastic rocks of assemblage 4 of the Rae cover sequence and correlative units contain detrital zircon in the 1.91-1.89 Ga age range (Laflamme et al. 2014; Partin et al. 2014; Wodicka et al. 2014). Assemblages 1 through 3 of the Rae cover sequence were deformed $\left(\mathrm{D}_{1}\right)$ during early Trans-Hudson orogenesis (Pehrsson et al. 2013) at ca. 1.9 Ga (Berman et al. 2007; Corrigan et al. 2009), prior to or during deposition of assemblage 4 units. In the Amer belt, the Itza Lake formation, representing assemblage 4, is virtually undeformed and metamorphic assemblages include clay minerals, indicating low-grade conditions (Jefferson et al. 2015). A small outlier of kaolinitic sandstone adjacent to the Amer belt was assigned an assemblage 4 designation and correlated with upper Montresor strata $110-180 \mathrm{~km}$ to the northeast (op cit.). However, in the Montresor belt proper, structural reconstruction indicates that the upper Montresor rocks were deformed by $\mathrm{D}_{1}$ thrusts and $\mathrm{D}_{2}$ extensional detachment prior to development of the upright Montresor syncline (Tschirhart and Percival, 2016; Percival and Tschirhart, submitted).The $\mathrm{D}_{2}$ low-angle, extensional fault is responsible for juxtaposing the greenschist-facies upper Montresor rocks with the amphibolite-facies lower Montresor units in the structural footwall complex (Percival et al. 2015b; Dziawa 2016). Combined, the geochronological, structural and metamorphic observations support assignment of upper Montresor strata in the Montresor belt to assemblage 3 of the Rae cover sequence. 
Taken together, the age constraints for the Montresor group suggest a minimum gap of ca. 120 m.y. between deposition of the lower Montresor group, prior to $2045 \pm 13 \mathrm{Ma}$, and the upper Montresor group, after 1923.8 = 5.9 Ma. In the Montresor belt, the contact is a syn-to post-metamorphic extensional detachment fault $\left(\mathrm{D}_{2}\right)$ separating the lower-grade upper Montresor group from the higher-grade lower Montresor group, such that the nature of the original relationship is undefined. However, in the Ketyet River belt to the south, the base of assemblage 3 is an unconformity (Rainbird et al. 2010).

Rainbird et al. (op cit.) drew attention to similarities between the Rae cover sequence and Hurwitz Group of the Hearne Province to the southeast (Fig. 1). In addition to four stratigraphic assemblages deposited over approximately the same time interval (2.3-1.9 Ga; Aspler et al. 2001), the lower quartz-rich formations contain detrital zircon exclusively of Archean age, whereas the upper Hurwitz (sequence 3) is dominated by grains of Paleoproterozoic age (ca. 2.35-1.911 Ga), inferred to have been derived from the Taltson-Thelon orogen to the west ((Fig. 1; Davis et al. 2005). A disconformity between sequences 2 and 3 corresponds to a ca. $150 \mathrm{~m} . \mathrm{y}$. depositional hiatus from 2.11 to $1.96 \mathrm{Ga}$. We note that the minimum ca. $120 \mathrm{~m}$.y. depositional gap between assemblages 2 and 3 in the Montresor group, bracketed by the new age constraints at 2.045-1.924 Ga, overlaps with the Hurwitz hiatus, supporting tentative linkages of the Rae and Hearne provinces prior to $1.9 \mathrm{Ga}$ (Aspler et al. 2001; Rainbird et al. 2010). However, the significance of the stratigraphic similarities remains uncertain in light of mounting structural, metamorphic and tectonic lineage evidence pointing to the Snowbird tectonic zone (Fig. 1) as the ca. 1.9 Ga suture between the Rae and Hearne provinces (Berman et al. 2007; Martel et al. 2008; Pehrsson et al. 2013b). 


\section{Regional Structural Considerations}

Results of the present study support broad correlation of Montresor belt strata with other parts of the Rae cover sequence, as well as with the Piling Group. Montresor quartz arenite was not sampled, because these rocks generally contain only Archean zircons (Rainbird et al. 2010), such that confirmation of correlation is not possible. However, accepting the lithological correlation of this unit as the regional stratigraphic base of the sequence, the lower Montresor quartz arenite is out of stratigraphic order, structurally overlying the wacke - mudstone dolostone unit (Fig. 4). However, this thrust fault, along with those imbricating basement with cover, have less offset than those of the Amer belt $50 \mathrm{~km}$ to the south, where $\mathrm{D}_{1}$ faults cut higher into the stratigraphic section (Patterson 1986; Calhoun et al. 2014; Jefferson et al. 2015).

Furthermore, Amer basal quartzite is isoclinally folded, implying a more ductile deformation style than that observed in the basal Montresor units. Together, these observations point to a more distal orogenic setting for the Montresor belt during $\mathrm{D}_{1}$ deformation.

The age of $\mathrm{D}_{1}$ deformation is not directly constrained by the present data set. In the southwest Rae, the Murmac Bay Group (Fig. 1) was metamorphosed and deformed during the Taltson orogeny (1940-1930 Ma) and Snowbird phase of the Trans-Hudson orogeny (1910-1900 Ma; Bethune et al. 2013). There is no record of the 1940-1930 Ma event in the Montresor belt, which has a younger tectonometamorphic history based on the age of metamorphic monazite growth beginning ca. $1870 \mathrm{Ma}$ (Davis et al. 2014; Percival et al. 2015b; Dziawa 2016). The deformational history of the belt is therefore related to effects of the Snowbird phase of the Trans-Hudson orogeny (Figs. 2, 14).

The $\mathrm{D}_{2}$ extensional event had significant effect in the Montresor belt, juxtaposing the thin-skinned deformation style of the upper Montresor with the thick-skinned structural footwall 
complex of imbricated basement and lower Montresor units. This event may also have been responsible for unroofing a region of granulite-facies rocks between the Amer and Montresor belts (Berman 2010), possibly along a north-dipping detachment ancestral to the Amer fault zone (Tella 1994; Percival et al. 2015b). In the Amer belt, Calhoun et al. (2013) recognized layerparallel detachment faults focused in carbonate beds, suggesting that late Trans-Hudsonian extensional features could be more widespread than previously appreciated (cf. Corrigan et al. 2009).

\section{Conclusions}

The lower Montresor group is exposed in a series of fault-bounded panels, imbricated with Archean basement along $\mathrm{D}_{1}$ thrust faults and out of stratigraphic order. Basal quartz arenite was not sampled for geochronology but is presumed to correlate with other quartz-rich members of the Rae cover sequence. An isolated panel of sub-arkosic arenite yielded a spectrum of detrital zircon ages with a cluster between 3.05 and $2.58 \mathrm{Ga}$ and a peak at $2194 \pm 14 \mathrm{Ma}$. The younger peak may define a single population, establishing the maximum age for deposition of the rock, and for imbrication with Archean basement gneisses. A second fault-bounded panel of wacke, mudstone and dolostone, lithologically similar to assemblage 2 of the Rae cover sequence, is cut by gabbro sills containing sparse zircon. Single grains yielded U-Pb ages of 2.71, 2.68, 2.53 and $2.39 \mathrm{Ga}$, whereas a pair of sharply faceted crystals provided an age of $2045 \pm 13 \mathrm{Ma}$. The Archean grains are interpreted to be inherited, whereas the younger zircons are inferred to represent the crystallization age of the gabbro, providing a lower limit on the age of sedimentation. Together, the data bracket deposition of part of the lower Montresor group between $2194 \pm 14$ and $2045 \pm 13 \mathrm{Ma}$, a constraint that may apply to correlative assemblage 2 units of the Rae cover sequence. 
The upper Montresor group comprises a sequence of fine-grained sandstone and siltstone, including calcareous varieties, with interbedded dolostone. Exposed in an open synclinal structure, these weakly metamorphosed units have been correlated with assemblage 3 of the Rae cover sequence (Rainbird et al. 2010). The detrital zircon population is dominated by Paleoproterozoic age peaks at 2.55-2.25 and 2.1-1.92 Ga, interpreted as being derived from the Queen Maud block and Thelon orogen to the west. The youngest concordant grain, at $1923.8 \pm$ 5.9 Ma provides a maximum age for submarine sandstone deposition. This may be close to the actual time of deposition, as the Thelon orogen continued to produce magmatic rocks until ca. $1890 \mathrm{Ma}$ (Berman et al. 2015b).

As part of the Rae cover sequence, the Montresor belt was deposited on basement affected less than 250 m.y. previously by the Arrowsmith orogeny (Berman et al. 2013a). Paradoxically, detritus of Arrowsmith age is absent from the 2.19-2.045 Ga lower units of the Montresor group but abundant in the $<1.924 \mathrm{Ga}$ unit. This could be explained if rocks produced during the Arrowsmith orogeny were not exhumed until the Taltson-Thelon orogeny, or the early stages of the Trans-Hudson orogeny.

\section{Acknowledgements}

This study was conducted as part of the Geo-mapping for Energy and Minerals Program (2008-2020). The work would not have been possible without field logistical support by the Polar Continental Shelf Program and Ookpik Aviation, field assistance by Chris Stieber, Vicki Tschirhart (2012), Angela Ford and Carolyn Dziawa (2014), and administrative support from the Nunavut Research Institute. Kim Kwok and Aleks Tiango are thanked for careful sample processing in the Jack Satterly Lab. Zircon mineral separates at the GSC were prepared by Raymond Chung and Ron Christie. Pat Hunt (SEM lab) and Tom Pestaj (SHRIMP lab) are 
thanked for their help in facilitating imaging and data acquisition. Discussions with colleagues Rob Berman, Kathryn Bethune, Charlie Jefferson, Judith Patterson, Sally Pehrsson, Rob Rainbird and Victoria Tschirhart added much appreciated knowledge and perspective. Rob Rainbird is thanked for critical comments on an earlier draft of the manuscript and journal reviewers Luke Beranek and Kathryn Bethune for their thorough and insightful reviews. ESS contribution number 20160297.

\section{References}

Ashton, K.E., Hartlaub, R.P., Bethune, K.M., Heaman, L.M., and Niebergall, G. 2013. New depositional age constraints for the Murmac Bay Group of the Southern Rae Province, Canada.

Precambrian Research, 232: 70-88.

Aspler, L.B., Chiarenzelli, J.R., Cousens, B.L., McNicoll, V.J., Davis, W.J. 2001.

Paleoproterozoic intracratonic basin processes, from breakup of Kenorland to assembly of Laurentia; Hurwitz Basin, Nunavut, Canada. Sedimentary Geology, 141-142: 287-318.

Berman, R.G. 2010. Metamorphic map of the western Churchill Province, Canada. Geological Survey of Canada, Open File 5279, scale 1: 2,500,000, 3 sheets +49 p. report, doi:10.4095/287320.

Berman, R.G., Sanborn-Barrie, M., Stern, R.A., and Carson, C.J. 2005. Tectonometamorphism at ca. 2.35 and $1.85 \mathrm{Ga}$ in the Rae domain, western Churchill Province, Nunavut, Canada: insights from structural, metamorphic and in situ geochronological analysis of the southwestern Committee Bay belt. Canadian Mineralogist, 43: 409-442. 
Berman, R.G., Davis, W.J., and Pehrsson, S. 2007. Collisional Snowbird tectonic zone resurrected: growth of Laurentia during the $1.9 \mathrm{Ga}$ accretionary phase of the Hudsonian orogeny. Geology, 35: 911-914.

Berman, R. G., Pehrsson, S., Davis, W.J., Ryan, J.J., Qui, H., and Ashton, K.E. 2013a. The Arrowsmith orogeny: geochronological and thermobarometric constraints on its extent and tectonic setting in the Rae craton, with implications for pre-Nuna supercontinent reconstruction. Precambrian Research, 232: 44-69.

Berman, R.G., Percival, J.A., Harris, J.R., Davis, W.J., McCurdy, M., Normandeau, P., Case, G., Nadeau, L., Hillary, E.M., Girard, E., Jefferson, C.W., Kellett, D., Camacho, A., Bethune, K.M., Pehrsson, S., and Hunt, P. 2013b. Geo-Mapping Frontiers' Chantrey project: Reconnaissance geology and economic potential of a transect across the Thelon tectonic zone, Queen Maud block, and adjacent Rae craton Geological Survey of Canada, Open File 7394, 1 sheet, doi:10.4095/292588.

Berman, R.G., Nadeau, L., Percival, J.A., Harris, J., Girard, É., Whalen, J.B., Davis. W.J., Kellett, D., Jefferson, C.W., Camacho, A., and Bethune, K. 2015a. Geo-Mapping Frontiers' Chantrey project: bedrock geology and multidisciplinary supporting data of a 550 kilometre transect across the Thelon tectonic zone, Queen Maud block, and adjacent Rae craton.

Geological Survey of Canada, Open File 7698, 39 pages (1 sheet), doi:10.4095/296202.

Berman, R.G., Davis. W.J., Whalen, J.B., McCurdy, M.W., Craven, J.A., Roberts, B.J., McMartin, I., Percival, J.A., Rainbird, R.H., Ielpi, A., Mitchell, R., Sanborn-Barrie, M., Nadeau, L., Girard, É., Carr, S., and Pehrsson, S.J. 2015b. Report of activities for the Geology and Mineral Potential of the Chantrey-Thelon Area: GEM-2 Thelon tectonic zone, Montresor belt 
and Elu basin projects. Geological Survey of Canada, Open File 7964, 19 pages, doi:10.4095/297302.

Bethune, K.M., Hunter, R.C., and Ashton, K.E. 2010. Age and provenance of the Paleoproterozoic Thluicho Lake Group based on detrital zircon U-Pb SHRIMP geochronology: New insights into the protracted tectonic evolution of the southwestern Rae Province, Canadian Shield: Precambrian Research, 182: 83-100.

Bethune, K.M., Berman, R.G., Rayner, N., and Ashton, K.E. 2013. Structural, petrological and in situ U-Pb SHRIMP geochronological study of the western Beaverlodge domain: implications for crustal architecture and multi-stage orogenesis in the southwestern Rae Province, Canadian Shield. Precambrian Research, 232: 89-118.

Bostock, H.H. and van Breemen, O., 1994. Ages of detrital and metamorphic zircons and monazites from a pre-Taltson magmatic zone basin at the western margin of Rae Province. Canadian Journal of Earth Sciences, 31: 1353-1364.

Buchan, K.L. and Ernst, R.E. 2013. Diabase dyke swarms of Nunavut, Northwest Territories and Yukon, Canada; Geological Survey of Canada, Open File 7464, 24 pages (1 sheet), doi: $10.4095 / 293149$

Calhoun, L., White, J.C., Jefferson, C.W., Patterson, J., and Tschirhart, V. 2014. Integrated geodatabase study of the complexly deformed U-hosting Paleoproterozoic Amer Group, Nunavut; Geological Survey of Canada, Scientific Presentation 19, 26 pages, doi:10.4095/293108. 
Corrigan, D., Pehrsson, S., Wodicka, N., and de Kemp, E. 2009. The Palaeoproterozoic TransHudson Orogen: A prototype of modern accretionary processes, In Ancient Orogens and Modern Analogues. Edited by J.B. Murphy, J.D. Keppie and A.J Hynes. Geological Society of London Special Publication 327: 457-479.

Davis, W.J., Rainbird, R.H., Aspler, L.B., Chiarenzelli, J.R. 2005. Detrital zircon geochronology of the Paleoproterozoic Hurwitz and Kiyuk Groups. Geological Survey of Canada (Current Research 2005-F1), 13 pages, doi:10.4095/216706.

Davis, W.J., Berman, R.G., and MacKinnon, A. 2013. U-Pb geochronology of archival rock samples from the Queen Maud Block, Thelon Tectonic Zone and Rae Craton, Kitikmeot region, Nunavut, Canada; Geological Survey of Canada, Open File 7409, 42 pages, doi:10.4095/292663.

Davis, W.J. Berman, R.G., Nadeau, L. and Percival, J.A. 2014. U-Pb zircon geochronology of a transect across the Thelon Tectonic Zone, Queen Maud region, and adjacent Rae craton, Kitikmeot Region, Nunavut, Canada. Geological Survey of Canada Open File 7652, 41 pages, doi:10.4095/295177.

Davis, W.J., Pehrsson, S.J., and Percival, J.A. 2015. Results of a U-Pb zircon geochronology transect across the southern Rae craton, Northwest Territories, Canada; Geological Survey of Canada, Open File 7655, 1 .zip file. doi:10.4095/295610.

Dickinson, W.R. and Gehrels, G.E. 2009. Use of U-Pb ages of detrital zircons to infer maximum depositional ages of strata: A test against a Colorado Plateau Mesozoic database. Earth and Planetary Science Letters 288: 115-125. 
Dziawa, C. 2016. Quantifying the pressure, temperature, and timing of metamorphism in the Montresor Belt, Nunavut, Canada. M.Sc. thesis, Department of Earth Sciences, Carleton University, Ottawa, ON, 213 p.

Ferderber, J., Kellett, D.A. and Wodicka, N. 2013. Exploring the Tehery region: correlating supracrustal sequences using detrital zircon geochronology, Rae Craton, Nunavut. Geological Survey of Canada, Open File 7424, 1 sheet, doi:10.4095/292709.

Fraser, J.A. 1988. Geology of the Woodburn Lake map area, District of Keewatin; Geological Survey of Canada, Paper 87-11, 12 pages (1 sheet), doi:10.4095/126936.

Frisch, T. 1992. Geology, Ian Calder Lake, District of Keewatin, Northwest Territories. Geological Survey of Canada, "A" Series Map 1780A, 1 sheet, doi:10.4095/183920.

Frisch, T. 2000. Precambrian geology of Ian Calder Lake, Cape Barclay, and part of Darby Lake map areas, south-central Nunavut; Geological Survey of Canada, Bulletin 542, 51 pages (2 sheets), doi:10.4095/211320.

Frisch, T. and Patterson, J.G. 1983. Preliminary Account of the Geology of the Montresor River area, District of Keewatin; in Current Research, Part A / Recherches en cours, Partie A; Geological Survey of Canada; Geological Survey of Canada, Paper 83-1A, p. 103-108.

Hadlari, T., Rainbird, R. H., and Pehrsson, S. J., 2004. Geology, Schultz Lake, Nunavut: Geological Survey of Canada, Open File 1839, 1 sheet, scale 1:250 000.

Heywood, W.W. 1961. Geological notes, northern District of Keewatin (parts of 56, 57, 66 and 67); Geological Survey of Canada, Paper 61-18, 9 p. 
Hinchey, A.M., Davis, W.J., Ryan, J.J., and Nadeau, L. 2011. Neoarchean high-potassium granites of the Boothia mainland area, Rae domain, Churchill Province: $\mathrm{U}-\mathrm{Pb}$ zircon and $\mathrm{Sm}-\mathrm{Nd}$ whole rock isotopic constraints: Canadian Journal of Earth Sciences, 48: 247-279.

Hoffman, P.F. 1989. Precambrian geology and tectonic history of North America. In The Geology of North America-An Overview. Edited by A.W., Bally and A.R. Palmer. Geological Society of America, Boulder, CO, pp. 447-512.

Jaffey, A.H., Flynn, K.F., Glendenin, L.E., Bentley, W.C. and Essling, A.M. 1971. Precision measurement of half-lives and specific activities of ${ }^{235} \mathrm{U}$ and ${ }^{238} \mathrm{U}$. Physical Review, 4: 18891906.

Jefferson, C.W., White, J.C., Young, G.M., Patterson, J., Tschirhart, V.L., Pehrsson, S.J., Calhoun, L., Rainbird, R.H., Peterson, T.D., Davis, W.J., Tella, S., Chorlton, L.B., Scott, J.M., Percival, J.A., Morris, W.A., Keating, P., Anand, A., Shelat, Y. and MacIsaac, D. 2015. Outcrop and remote predictive geology of the Amer Belt and basement beside and beneath the northeast Thelon Basin, in parts of NTS 66-A, B, C, F, G and H, Kivalliq Region, Nunavut. Geological Survey of Canada, Open File 7242; 1 sheet, doi:10.4095/296825.

Krogh, T.E. 1973. A low contamination method for hydrothermal decomposition of zircon and extraction of $\mathrm{U}$ and $\mathrm{Pb}$ for isotopic age determinations. Geochimica et Cosmochimica Acta, 37: $485-494$.

LaFlamme, C., McFarlane, C.R.M., Corrigan, D., and Wodicka, N. 2014. Origin and tectonometamorphic history of the Repulse Bay block, Melville Peninsula, Nunavut: exotic terrane or deeper level of the Rae craton? Canadian Journal of Earth Sciences, 51: 1097-1122. 
Ludwig, K.R. 2003. Using Isoplot/Ex, Version 3, A Geochronological Toolkit for Microsoft Excel: Berkeley Geochronology Center Special Publication 4.

Ludwig, K. 2009, SQUID 2: A User's Manual, rev. 12 Apr, 2009. Berkeley Geochronology Center Special Publication 5, 110 p.

Martel, E., van Breemen, O., Berman, R.G., and Pehrsson, S. 2008. Geochronology and tectonometamorphic history of the Snowbird Lake area, Northwest Territories, Canada: new insights into the architecture and significance of the Snowbird tectonic zone. Precambrian Research, 161: 201-230.

McDonough, M.R., McNicoll, V.J., Schetselaar, E.M. and Grover, T.W. 2000. Geochronological and kinematic constraints on crustal shortening and escape in a two-sided oblique-slip collisional and magmatic orogen, Paleoproterozoic Taltson magmatic zone, northeastern Alberta. Canadian Journal of Earth Sciences, 37: 1549-1573.

McNicoll, V., Thériault, R.J. and McDonough, M.R., 2000. Taltson basement gneissic rocks: U$\mathrm{Pb}$ and $\mathrm{Nd}$ isotopic constraints on the basement to the Paleoproterozoic Taltson magmatic zone, northeastern Alberta. Canadian Journal of Earth Sciences, 37: 1575-1596.

Morgan, W.C., Bourne, J., Herd, R.K., Pickett, J.W., and Tippett, C.R. 1975. Geology of the Foxe Fold Belt, Baffin Island, District of Franklin, in Report of Activities, Part A: Geological Survey of Canada Paper 75-1A, p. 343-347.

Partin, C.A., Bekker, A., Corrigan, D., Modeland, S., Francis, D. and Davis, D.W. 2014.

Sedimentological and geochemical basin analysis of the Paleoproterozoic Penrhyn and Piling groups of Arctic Canada. Precambrian Research, 251: 80-101. 
Patterson, J.G. 1986. The Amer Belt: remnant of an Aphebian foreland fold and thrust belt. Canadian Journal of Earth Sciences, 23: 2012-2023.

Pehrsson, S.J., Jenner, G., Kjarsgaard, B.A. 2002. The Ketyet River group: correlation with Paleoproterozoic supracrustal sequences of northeastern Rae and implications for Proterozoic orogenesis in the western Churchill Province. In: Geological Association of Canada Annual Meeting, p. 90 (Abstracts with Programs v. 27).

Pehrsson, S., Berman, R.G., and Davis, W.J. 2013a. Paleoproterozoic orogenesis during Nuna aggregation: a case study of reworking of the Archean Rae craton, Woodburn Lake, Nunavut. Precambrian Research, 232: 167-188.

Pehrsson, S., Berman, R.G., Eglington, B., and Rainbird, R.H. 2013b. The case for a Rae family of cratons. Precambrian Research, 232: 27-43.

Percival, J.A., and Tschirhart, V., Trans-Hudsonian far-field deformation effects in the Rae foreland: An integrated geological- 3D magnetic model. Submitted to Tectonophysics.

Percival, J.A., Tschirhart, V., Ford, A., and Dziawa, C. 2015a. Report of activities for geology and mineral potential of the Chantrey-Thelon Area: GEM-2 Montresor project; Geological Survey of Canada, Open File 7707, 12 p. doi:10.4095/295673.

Percival, J.A., Tschirhart, V., Davis, W.J., Berman, R.G., and Ford, A. 2015b. Geology, Montresor River area, Nunavut, parts of NTS 66-H and NTS 66-I; Geological Survey of Canada, Canadian Geoscience Map 231 (preliminary), scale 1:100 000. doi:10.4095/29691 
Peterson, T.D., Pehrsson, S., Skulski, T. and Sandeman, H. 2010. Compilation of Sm-Nd Isotope Analyses of Igneous Suites, Western Churchill Province. Geological Survey of Canada, Open File 6439, 18 pages; 1 CD-ROM, doi:10.4095/285360.

Peterson, T.D., Jefferson, C.W., and Anand, A. 2015. Geological setting and geochemistry of the ca. 2.6 Ga Snow Island Suite in the central Rae Domain of the Western Churchill Province, Nunavut. Geological Survey of Canada, Open File 7841, 29 pages, doi:10.4095/296599

Pettijohn, F.J., Potter, P.E. and Siever, R. 1987. Sand and Sandstone, 2nd ed., Springer-Verlag, Berlin.

Rainbird, R.H., Davis, W. J., Pehrsson, S., Wodicka, N., Rayner, N. and Skulski, T. 2010. Early Paleoproterozoic supracrustal assemblages of the Rae domain, Nunavut, Canada: intracratonic basin development during supercontinent break-up and assembly. Precambrian Research, 181: $167-186$.

Rayner, N., Sanborn-Barrie, M., and Chakungal, J. 2013. A 3.0 to 2.0 Ga plutonic record on Southampton Island, Nunavut. Geological Survey of Canada, Current Research 2013-6. 18 p. doi:10.4095/292214.

Sanborn-Barrie, M., Davis, W. J., Berman, R.G., Rayner, N., Skulski, T. and Sandeman, H. 2014. Neoarchean continental crust formation and Paleoproterozoic deformation of the central Rae craton, Committee Bay belt, Nunavut. Canadian Journal of Earth Sciences, 51: 635-667.

Schultz, M.E.J., Chacko, T., Heaman, L.M., Sandeman, H.A., Simonetti, A., and Creaser, R.A. 2007. Queen Maud block: A newly recognized Paleoproterozoic (2.4-2.5 Ga) terrane in northwest Laurentia. Geology, 35: 707-710. 
Sircombe, K.N. 2004. AGEDISPLAY: an Excel workbook to evaluate and display univariate geochronological data using binned frequency histograms and probability density distributions. Computers and Geosciences, 30: 21-31. doi:10.1016/j.cageo.2003.09.006.

St-Onge, M.R., van Gool, J.A.M., Garde, A.A., and Scott, D.J. 2009. Correlation of Archaean and Palaeoproterozoic units between northeastern Canada and western Greenland: Constraining the pre-collisional upper plate accretionary history of the Trans-Hudson orogen. In Earth Accretionary Systems in Space and Time. Edited by P.A. Cawood and A. Kröner. Geological Society [London] Special Publication 318: 193-235.

Stern, R.A. 1997. The GSC Sensitive High Resolution Ion Microprobe (SHRIMP): analytical techniques of zircon $\mathrm{U}-\mathrm{Th}-\mathrm{Pb}$ age determinations and performance evaluation. Geological Survey of Canada, Current Research, v. 1997-F, p. 1-31.

Stern, R.A., and Amelin, Y. 2003. Assessment of errors in SIMS zircon U-Pb geochronology using a natural zircon standard and NIST SRM 610 glass: Chemical Geology, 197: 111-142.

Tella, S. 1994. Geology, Amer Lake (66H), Deep Rose Lake (66G) and parts of Pelly Lake (66F), District of Keewatin, Northwest Territories, Open File 2969, scale 1:250,000, 1 sheet, doi:10.4095/194789.

Tella, S., Hanmer, S., Sandeman, H.A., Ryan, J.J., Mills, A., Davis, W.J., Berman, R.G., Wilkinson, L., Kerswill, J.A. 2001. Geology, MacQuoid Lake-Gibson Lake-Cross Bay-Akunak Bay region, western Churchill Province, Nunavut. Geological Survey of Canada Map 2008A, scale 1:100,000, 1 sheet; 1 CD-ROM, doi:10.4095/212827. 
Tersmette, D.B. 2012. Geology, geochronology, thermobarometry, and tectonic evolution of the Queen Maud block, Churchill craton, Nunavut, Canada. MSc. thesis, University of Alberta, Department of Earth and Atmospheric Sciences, Edmonton, AB.

Tschirhart, V., and Percival, J.A. 2016. Toward 3D structural constraints from magnetic models: an example from the Montresor belt, Nunavut, Canada . Australian Society of Exploration Geophysicists Extended Abstracts 2016(1) 1-3. doi:10.1071/ASEG2016ab175

Tschirhart, V., Morris, W.A., Jefferson, C.W., Keating, P., White, J.C. and Calhoun, L. 2013. 3D geophysical inversions of the north-east Amer Belt and their relationship to the geologic structure. Geophysical Prospecting, 61: 547-560.

Tschirhart, V., Percival, J.A., and Jefferson, C.W. 2015. Geophysical models of the Montresor metasedimentary belt and its environs, central Nunavut, Canada. Canadian Journal of Earth Sciences, 52: 833-845.

van Breemen, O., Thompson, P.H., Hunt, P.A., and Culshaw, N., 1987. U - Pb zircon and monazite geochronology from the northern Thelon Tectonic Zone, District of Mackenzie; Geological Survey of Canada Paper, 87-2: 81-93.

van Breemen, O., Kjarsgaard, B.A., Tella, S., Lemkow, D. and Aspler, L. 2013. U-Pb detrital zircon geochronology of clastic sedimentary rocks of the Paleoproterozoic Nonacho and East Arm basins, Thaidene Nene MERA study area. In Mineral and Energy Resource Assessment of the proposed Thaidene Nene National Park Reserve in the area of the east arm of Great Slave Lake, Northwest Territories. Edited by D.F. Wright, E.J. Ambrose, D. Lemkow and G. BonhamCarter. Geological Survey of Canada, Open File 7196, pp. 119-142. 
Wodicka, N., St-Onge, M.R., Corrigan, D., Scott, D.J. and Whalen, J.B. 2014. Did a proto-ocean basin form along the southeastern Rae cratonic margin? Evidence from U-Pb geochronology, geochemistry (Sm-Nd and whole-rock), and stratigraphy of the Paleoproterozoic Piling Group, northern Canada. Geological Society of America Bulletin 126: 1625-1653.

Zaleski, E., Pehrsson, S.J., Duke, N., Davis, W.J., L’Heureux, R., Grenier, E., Kerswill, J.A. 2000. Quartzite sequences and their relationships, Woodburn Lake group, western Churchill Province, Nunavut. Geological Survey of Canada, Current Research, no. 2000-C7, 10 p. 
Appendix 1: Analytical Methods

\section{SHRIMP (Sensitive High-Resolution Ion MicroProbe)}

Samples were crushed by mechanical disaggregation, followed by sieving, and density separation using water panning at the Geochronology facility, GSC, Ottawa. SHRIMP analytical procedures modified from those described by Stern (1997), with standards and U-Pb calibration methods following Stern and Amelin (2003). Details regarding the procedure, or any deviations from it, are noted in the section relating to specific samples. Briefly, zircons were cast in $2.5 \mathrm{~cm}$ diameter epoxy mounts (along with fragments of the GSC laboratory standard zircon; z6266, with $206 \mathrm{~Pb} / 238 \mathrm{U}$ age $=559 \mathrm{Ma}$ ). The mid-sections of the zircons were exposed using 9, 6, and 1 $\mu \mathrm{m}$ diamond compound, and the internal features of the zircons (such as zoning, structures, alteration, etc.) were characterized in back-scattered electron mode (BSE) utilizing a Zeiss Evo 50 scanning electron microscope. The count rates at eleven masses including background were sequentially measured with a single electron multiplier. Off-line data processing was accomplished using SQUID2 (version 2.5; Ludwig 2009). The $1 \sigma$ external errors of ${ }^{206} \mathrm{~Pb} /{ }^{238} \mathrm{U}$ ratios reported in the data table incorporate the error in calibrating the standard. Common $\mathrm{Pb}$ correction utilized the $\mathrm{Pb}$ composition of the surface blank (Stern 1997). Yb and Hf concentration data were calculated using sensitivity factors derived from standard 6222 with values of 229 and 8200 ppm respectively. Isoplot v. 3.00 (Ludwig 2003) was used to generate concordia plots and calculate regression ages and weighted means. The error ellipses on the concordia diagrams and the weighted mean errors are reported at $95 \%$ confidence intervals. Run condition for individual analytical sessions are given in Table 2.

\section{TIMS (Thermal Ionization Mass Spectrometry)}


Samples were processed in the Jack Satterly Geochronology Lab at the University of Toronto. Conventional crushing and grinding techniques (jaw crusher and disc mill) were employed, followed by a shaking water (Wilfley) table procedure to obtain a heavy mineral concentrate, and finally by Frantz magnetic and methylene iodide heavy liquid separations. Extra precaution was made to prevent any possible sample cross-contamination since the anticipated recovery of datable accessory phases in this rock was low. Following hand-picking of the best quality, fresh zircon, selected grains were photographed and then analyzed using conventional isotope dilution - thermal ionization mass spectrometry (ID-TIMS) methods. Zircons were pretreated with a chemical abrasion procedure involving annealing at $1000^{\circ} \mathrm{C}$ for $48 \mathrm{hrs}$ and leaching in a dilute mixture of $\mathrm{HF}: \mathrm{HNO}_{3}$ for several hours at $200^{\circ} \mathrm{C}$. Final weight estimates were made from a digital measurement of grain dimensions and the mineral's density. Zircon grains were washed on parafilm and loaded into Teflon bombs with concentrated $\mathrm{HF}$ along with a mixed ${ }^{205} \mathrm{~Pb}-{ }^{235} \mathrm{U}$ isotopic tracer solution (Krogh 1973). Dissolution occurred over three-four days at $195^{\circ} \mathrm{C}$, after which fractions were dried down with phosphoric acid and loaded with silica gel directly onto outgassed rhenium filaments. Larger grain dissolutions were passed through ion exchange columns to obtain purified elutions of $\mathrm{Pb}$ and $\mathrm{U}$. The isotopic compositions of $\mathrm{Pb}$ and $\mathrm{U}$ were measured using a single Daly collector with a pulse counting detector on a solid source VG354 mass spectrometer. A detector mass discrimination of $0.053 \%$ per atomic mass unit (AMU) and a dead time of 20 nsec were employed for Daly detector measurements. A thermal source mass discrimination correction of $0.1 \%$ per atomic mass unit was applied for both $\mathrm{Pb}$ and $\mathrm{U}$. The assigned laboratory blank for $\mathrm{U}$ was $0.2 \mathrm{pg}$, while that for $\mathrm{Pb}$ is routinely measured below $1 \mathrm{pg}$. Error estimates were calculated by propagating known sources of analytical uncertainty for each analysis including within-run ratio variability, uncertainty in the fractionation correction, and 
uncertainties in the isotopic composition of laboratory blank. Uncertainties for the ID-TIMS data are given at the $95 \%(2 \sigma)$ confidence level. Initial corrections were made using an in-house data reduction program (UTILAGE). Decay constants used in age calculations are those of Jaffey et al. (1971). Graphical data presentation and quoted ages were generated using the Microsoft Excel Add-in Isoplot/Ex v. 3.00 of Ludwig (2003). 


\section{FIGURE CAPTIONS}

Figure 1: Regional geology of the northwestern Canadian Shield (after Aspler et al. 2001; Rainbird et al. 2010; Buchan and Ernst 2013; Davis et al. 2015) showing location of features referred to in the text, including dashed box: Figure 2; A: Amer belt; B: Boomerang belt; C: Chantrey belt; CB: Chesterfield block; HG: Hurwitz group; K: Ketyet River belt; M: Montresor belt: Md: MacQuoid dyke swarm; Mu: Murmac Bay group; N: Nonacho basin; PD: Penylan domain; Pe: Penrhyn Group; Pi: Piling Group; QMB: Queen Maud block; SI: Southampton Island; STZ: Snowbird tectonic zone; TTZ: Thelon tectonic zone; TMZ: Taltson magmatic zone; T: Tehery belt; Td: Tulemalu dyke swarm; Tl: Thluicho group. Patterned areas in the central Rae are the mid-Proterozoic Athabasca (At), Baker $(\mathrm{Ba})$ and Thelon (Th) sedimentary basins.

Figure 2: Summary of Paleoproterozoic geological events of the Rae Province.

Figure 3: Simplified geology of the Montresor belt (after Percival et al. 2015b; Frisch 1992; Tella 1994) showing major features referred to in the text. Box shows location of figure 4.

Figure 4. Geology of the northeastern Montresor belt (after Percival et al. 2015b), showing location of dated samples.

Figure 5: Field photographs of dated units of the Montresor belt. a) pale pink, sub-arkosic arenite (sample 1: 14PBA-029; 11289) from the lower Montresor group. The unit occurs as a faultbound panel in the structural footwall complex; b) granodiorite sill (sample 2: 14PBA-027D; 11291)(chipped, positive-weathering, $12 \mathrm{~cm}$ wide body), lower Montresor group; c) pegmatitic gabbro (sample 3: 12PBAB-017E) from $20 \mathrm{~cm}$ boudin in wacke, lower Montresor group; d) cross-bedded, fine-grained arkosic sandstone (sample 4: 12PBAB-19A; 11290), upper Montresor group. 
Figure 6: Photomicrograph of the zircon population in sub-arkosic arenite (sample 1: 14PBA029; 11289) of the lower Montresor group, prior to mounting for imaging and SHRIMP analysis.

Figure 7: Summary of detrital zircon U-Pb data for sub-arkosic arenite sample 1 (14PBA-029; 11289) of the lower Montresor group, shown on combined probability density plot (darker fill indicates data screened for $95-105 \%$ concordance, lighter grey fill includes all data) and histograms (grey outline; bin width $=20 \mathrm{Ma}$ ).

Figure 8: Concordia diagram for U-Pb zircon data from sample 2 (14PBA-027D; 11291).

Figure 9: Representative, largely prismatic igneous zircon population from pegmatitic gabbro, 12PBA-B017E (sample 2). Selected zircons chosen for analysis are labelled (Z1-Z6).

Figure 10: Concordia diagram for U-Pb zircon data from sample 3 (12PBA-B017E). a) full data set for individual grain analyses. Discordant oldest four fractions (shaded ellipses) are interpreted to be xenocrystic in origin. Inset (b) shows area for youngest two fractions; unshaded ellipses. b) enlarged region with detail for most sharply faceted short prisms Z2 and Z5.

Figure 11: Thin section photomicrographs of upper Montresor sandstone (sample 4: 12PBAB19A; 11290) showing a) heavy mineral bands outlined by magnetite (opaque, between arrows); b) close-up showing a variety of heavy minerals including magnetite (mt), tourmaline (tm), apatite (ap) and zircon (zr).

Figure 12: Photomicrograph of the zircon population in sandstone of the upper Montresor group (sample 4: 12PBAB-19A; 11290), prior to mounting for imaging and SHRIMP analysis.

Figure 13: Summary of detrital zircon $\mathrm{U}-\mathrm{Pb}$ data for cross-bedded arkosic sandstone sample 4 (12PBAB-19A; 11290) of the upper Montresor group, shown on combined probability density 
plot (darker fill indicates data screened for $95-105 \%$ concordance, lighter grey fill includes all data) and histograms (grey outline; bin width $=20 \mathrm{Ma}$ ).

Figure 14: Summary of proposed correlations within the Rae cover sequence, updated from Rainbird et al. (2010)(Amer and Ketyet River groups) by including recent data from the Montresor group (this paper), Piling group (Wodicka et al. 2014) and Penhryn group (Partin et al. 2014). Assemblages 1, 2 and 3 were deformed during the ca. 1.9 Ga Snowbird phase of the Trans-Hudson orogeny prior to deposition of assemblage 4 and subsequent deformation during the main phase of the Trans-Hudson orogeny, ca. 1.85-1.78 Ga. 
Table 1: U-Pb SHRIMP analytical data

\begin{tabular}{|c|c|c|c|c|c|c|c|c|c|c|c|c|c|c|c|c|c|c|c|c|c|c|c|}
\hline \multirow[b]{2}{*}{ Spot name } & \multirow[b]{2}{*}{$\begin{array}{c}\text { U } \\
(\mathrm{ppm})\end{array}$} & \multirow[b]{2}{*}{$\begin{array}{c}\text { Th } \\
\text { (ppm) }\end{array}$} & \multirow[b]{2}{*}{$\frac{T h}{U}$} & \multirow[b]{2}{*}{$\begin{array}{c}\mathrm{Yb} \\
(\mathrm{ppm})\end{array}$} & \multirow[b]{2}{*}{$\begin{array}{c}\mathbf{H f} \\
(\mathrm{ppm})\end{array}$} & \multirow[b]{2}{*}{$\frac{{ }^{204} \mathrm{~Pb}}{{ }^{206} \mathrm{~Pb}}$} & \multirow[b]{2}{*}{$\begin{array}{l}\% \\
\text { err }\end{array}$} & \multirow[b]{2}{*}{$f(206)^{204}$} & \multirow[b]{2}{*}{$\begin{array}{l}{ }^{206} \mathrm{~Pb}^{*} \\
\text { (ppm) }\end{array}$} & \multirow[b]{2}{*}{$\frac{{ }^{208^{*}} \mathrm{~Pb}}{{ }^{206^{*}} \mathrm{~Pb}}$} & \multicolumn{4}{|c|}{ Atomic Ratios } & \multicolumn{7}{|c|}{ Model Age (Ma) } & \multirow[b]{2}{*}{$\frac{ \pm^{207} \mathrm{~Pb}}{{ }^{206} \mathrm{~Pb}}$} & \multirow[b]{2}{*}{$\begin{array}{c}\text { Disc. } \\
(\%)\end{array}$} \\
\hline & & & & & & & & & & & $\begin{array}{l}\% \\
\text { err }\end{array}$ & $\frac{{ }^{207^{*}} \mathrm{~Pb}}{{ }^{235} \mathrm{U}}$ & $\begin{array}{l}\% \\
\text { err }\end{array}$ & $\frac{\frac{206^{*} \mathrm{~Pb}}{{ }^{238} \mathrm{U}}}{{ }^{238}}$ & $\begin{array}{l}\% \\
\text { err }\end{array}$ & $\begin{array}{l}\text { Corr } \\
\text { Coeff }\end{array}$ & $\frac{{ }^{207^{*}} \mathrm{~Pb}}{206^{*} \mathrm{~Pb}}$ & $\begin{array}{l}\% \\
\text { err }\end{array}$ & $\frac{{ }^{206} \mathrm{~Pb}}{{ }^{238} \mathrm{U}}$ & $\pm_{\frac{{ }^{206} \mathrm{~Pb}}{{ }^{238} \mathrm{U}}}$ & $\frac{{ }^{207} \mathrm{~Pb}}{{ }^{206} \mathrm{~Pb}}$ & & \\
\hline \multicolumn{24}{|c|}{$\begin{array}{l}\text { SAMPLE 1: Sub-arkosic arenite 14PBA-029; } 11289 \text { (66.3419, -96.5780) } \\
\end{array}$} \\
\hline $11289-001.1$ & 80 & 51 & 0.66 & 163 & 9824 & $5.4 \mathrm{E}-04$ & 24 & 0.94 & 27.7 & 0.196 & 5.0 & 7.522 & 2.2 & 0.4029 & 1.4 & 0.631 & 0.1354 & 1.7 & 2183 & 26 & 2169 & 30 & -1 \\
\hline $11289-003.1$ & 52 & 38 & 0.76 & 155 & 9507 & $3.1 \mathrm{E}-04$ & 41 & 0.55 & 17.7 & 0.227 & 5.7 & 7.553 & 2.4 & 0.3957 & 1.6 & 0.641 & 0.1384 & 1.9 & 2149 & 28 & 2208 & 32 & +3 \\
\hline 11289-004.1 & 63 & 30 & 0.49 & 118 & 8906 & $1.5 \mathrm{E}-04$ & 58 & 0.27 & 27.1 & 0.112 & 8.0 & 13.276 & 2.1 & 0.5010 & 1.7 & 0.779 & 0.1922 & 1.3 & 2618 & 36 & 2761 & 22 & +6 \\
\hline 11289-005.1 & 53 & 33 & 0.65 & 124 & 9905 & $-1.3 \mathrm{E}-04$ & 71 & -0.23 & 17.6 & 0.217 & 5.9 & 7.793 & 2.3 & 0.3901 & 1.6 & 0.691 & 0.1449 & 1.7 & 2123 & 29 & 2286 & 29 & +8 \\
\hline 11289-006.1 & 51 & 36 & 0.73 & 143 & 9231 & 5.6E-04 & 33 & 0.97 & 17.0 & 0.206 & 6.9 & 7.163 & 3.0 & 0.3894 & 1.6 & 0.556 & 0.1334 & 2.5 & 2120 & 30 & 2143 & 43 & +1 \\
\hline 11289-008.1 & 54 & 27 & 0.52 & 111 & 9900 & 1.1E-04 & 58 & 0.19 & 33.3 & 0.139 & 5.8 & 32.122 & 1.9 & 0.7206 & 1.7 & 0.873 & 0.3233 & 0.9 & 3498 & 45 & 3586 & 14 & +3 \\
\hline 11289-014.1 & 67 & 42 & 0.66 & 133 & 9307 & $4.2 \mathrm{E}-04$ & 32 & 0.74 & 24.1 & 0.168 & 6.3 & 7.792 & 2.4 & 0.4203 & 1.5 & 0.626 & 0.1345 & 1.9 & 2262 & 29 & 2157 & 33 & -6 \\
\hline 11289-015.1 & 33 & 27 & 0.84 & 71 & 8996 & 5.9E-04 & 33 & 1.01 & 15.0 & 0.260 & 6.2 & 13.577 & 2.6 & 0.5245 & 1.8 & 0.691 & 0.1877 & 1.9 & 2718 & 40 & 2722 & 31 & +0 \\
\hline 11289-016.1 & 113 & 63 & 0.57 & 140 & 10321 & 1.9E-04 & 33 & 0.33 & 46.6 & 0.156 & 4.2 & 10.849 & 1.6 & 0.4799 & 1.3 & 0.807 & 0.1640 & 1.0 & 2527 & 28 & 2497 & 16 & -1 \\
\hline 11289-020.1 & 79 & 44 & 0.57 & 211 & 8078 & $2.5 \mathrm{E}-04$ & 35 & 0.44 & 34.4 & 0.153 & 5.5 & 15.089 & 1.9 & 0.5091 & 1.6 & 0.821 & 0.2150 & 1.1 & 2653 & 34 & 2943 & 17 & +12 \\
\hline 11289-023.1 & 96 & 87 & 0.94 & 269 & 9895 & 4.1E-04 & 27 & 0.71 & 32.5 & 0.249 & 4.0 & 7.252 & 2.0 & 0.3957 & 1.3 & 0.662 & 0.1329 & 1.5 & 2149 & 25 & 2137 & 27 & -1 \\
\hline $11289-028.1$ & 53 & 60 & 1.17 & 273 & 9334 & $-1.1 \mathrm{E}-04$ & 71 & -0.20 & 18.4 & 0.350 & 4.2 & 8.078 & 2.2 & 0.4070 & 1.6 & 0.710 & 0.1439 & 1.6 & 2201 & 29 & 2275 & 27 & +4 \\
\hline 11289-029.1 & 220 & 213 & 1.00 & 115 & 7697 & $3.5 \mathrm{E}-04$ & 18 & 0.60 & 90.4 & 0.301 & 2.2 & 12.163 & 1.4 & 0.4780 & 1.2 & 0.859 & 0.1845 & 0.7 & 2519 & 26 & 2694 & 12 & +8 \\
\hline 11289-032.1 & 81 & 65 & 0.82 & 161 & 9693 & 1.1E-04 & 58 & 0.18 & 35.8 & 0.231 & 7.4 & 13.026 & 1.9 & 0.5136 & 1.5 & 0.802 & 0.1839 & 1.1 & 2672 & 33 & 2689 & 18 & +1 \\
\hline 11289-037.1 & 72 & 69 & 0.99 & 194 & 9819 & $2.8 \mathrm{E}-04$ & 33 & 0.49 & 34.2 & 0.256 & 4.0 & 16.174 & 1.8 & 0.5507 & 1.5 & 0.811 & 0.2130 & 1.1 & 2828 & 34 & 2929 & 17 & +4 \\
\hline 11289-044.1 & 53 & 32 & 0.62 & 136 & 9763 & 5.5E-04 & 33 & 0.95 & 18.7 & 0.176 & 11.1 & 7.701 & 2.9 & 0.4117 & 1.7 & 0.573 & 0.1357 & 2.4 & 2223 & 31 & 2172 & 41 & -3 \\
\hline 11289-047.1 & 161 & 86 & 0.55 & 229 & 8805 & $9.8 \mathrm{E}-05$ & 41 & 0.17 & 71.2 & 0.153 & 3.6 & 14.371 & 1.4 & 0.5151 & 1.3 & 0.870 & 0.2023 & 0.7 & 2678 & 28 & 2845 & 12 & +7 \\
\hline 11289-048.1 & 46 & 30 & 0.67 & 136 & 9251 & 1.1E-03 & 26 & 1.87 & 14.9 & 0.188 & 8.8 & 7.077 & 3.7 & 0.3816 & 1.7 & 0.468 & 0.1345 & 3.3 & 2084 & 31 & 2158 & 57 & +4 \\
\hline $11289-052.1$ & 110 & 98 & 0.92 & 352 & 8704 & $1.3 \mathrm{E}-04$ & 35 & 0.23 & 59.9 & 0.254 & 5.4 & 22.245 & 1.5 & 0.6334 & 1.3 & 0.892 & 0.2547 & 0.7 & 3163 & 33 & 3214 & 11 & +2 \\
\hline 11289-055.1 & 46 & 23 & 0.52 & 112 & 9672 & $1.8 \mathrm{E}-04$ & 58 & 0.31 & 16.6 & 0.132 & 12.3 & 7.737 & 2.4 & 0.4160 & 1.6 & 0.665 & 0.1349 & 1.8 & 2242 & 31 & 2162 & 32 & -4 \\
\hline 11289-058.1 & 139 & 133 & 0.99 & 366 & 9649 & --- & --- & 0.00 & 47.8 & 0.288 & 2.9 & 7.561 & 1.6 & 0.3996 & 1.3 & 0.820 & 0.1372 & 0.9 & 2167 & 23 & 2193 & 15 & +1 \\
\hline 11289-060.1 & 199 & 221 & 1.15 & 149 & 11337 & $4.2 \mathrm{E}-04$ & 17 & 0.74 & 96.9 & 0.218 & 4.0 & 16.789 & 1.6 & 0.5677 & 1.2 & 0.769 & 0.2145 & 1.0 & 2898 & 28 & 2940 & 16 & +2 \\
\hline 11289-066.1 & 70 & 51 & 0.76 & 176 & 9824 & $5.1 \mathrm{E}-04$ & 32 & 0.89 & 24.4 & 0.199 & 6.4 & 7.699 & 3.8 & 0.4081 & 1.7 & 0.443 & 0.1368 & 3.4 & 2206 & 32 & 2187 & 60 & -1 \\
\hline 11289-067.1 & 108 & 105 & 1.01 & 312 & 9263 & 2.7E-04 & 32 & 0.47 & 37.2 & 0.282 & 3.5 & 7.438 & 1.8 & 0.4027 & 1.3 & 0.748 & 0.1340 & 1.2 & 2182 & 25 & 2150 & 21 & -2 \\
\hline 11289-070.1 & 81 & 73 & 0.92 & 295 & 9420 & $2.2 \mathrm{E}-04$ & 41 & 0.37 & 29.2 & 0.282 & 4.0 & 7.830 & 1.9 & 0.4177 & 1.4 & 0.747 & 0.1360 & 1.3 & 2250 & 27 & 2176 & 22 & -4 \\
\hline 11289-071.1 & 137 & 129 & 0.97 & 341 & 9670 & $1.9 \mathrm{E}-04$ & 29 & 0.33 & 67.7 & 0.274 & 2.6 & 16.254 & 1.5 & 0.5740 & 1.3 & 0.867 & 0.2054 & 0.7 & 2924 & 30 & 2869 & 12 & -2 \\
\hline
\end{tabular}




$\begin{array}{rrrrrrrr}11289-073.1 & 63 & 37 & 0.61 & 132 & 9617 & -5.4 \mathrm{E}-03 & 10 \\ 11289-074.1 & 181 & 60 & 0.34 & 105 & 11363 & 2.5 \mathrm{E}-05 & 71 \\ 11289-078.1 & 93 & 88 & 0.98 & 287 & 9541 & 3.3 \mathrm{E}-04 & 32 \\ 11289-079.1 & 159 & 79 & 0.51 & 90 & 10606 & 7.8 \mathrm{E}-05 & 41 \\ 11289-081.1 & 179 & 65 & 0.37 & 171 & 9917 & 2.6 \mathrm{E}-05 & 71 \\ 11289-084.1 & 145 & 60 & 0.43 & 240 & 9760 & 3.8 \mathrm{E}-05 & 58 \\ 11289-086.1 & 192 & 273 & 1.47 & 191 & 9187 & 7.7 \mathrm{E}-05 & 38 \\ 11289-087.1 & 65 & 53 & 0.83 & 206 & 9485 & 8.7 \mathrm{E}-05 & 71 \\ 11289-088.1 & 86 & 38 & 0.46 & 163 & 11721 & 3.3 \mathrm{E}-04 & 30 \\ 11289-092.1 & 96 & 64 & 0.70 & 166 & 10523 & 2.3 \mathrm{E}-04 & 32 \\ 11289-095.1 & 39 & 24 & 0.63 & 126 & 9043 & 7.5 \mathrm{E}-04 & 33 \\ 11289-096.1 & 42 & 25 & 0.61 & 115 & 9611 & 9.9 \mathrm{E}-04 & 29 \\ 11289-097.1 & 231 & 101 & 0.45 & 224 & 7760 & 8.9 \mathrm{E}-05 & 33 \\ 11289-098.1 & 47 & 2 & 0.03 & 112 & 11464 & 6.9 \mathrm{E}-04 & 24 \\ 11289-099.1 & 28 & 18 & 0.68 & 129 & 9158 & 3.4 \mathrm{E}-04 & 58 \\ 11289-101.1 & 51 & 33 & 0.68 & 134 & 9607 & 3.8 \mathrm{E}-04 & 38 \\ 11289-102.1 & 140 & 62 & 0.46 & 218 & 10591 & -1.4 \mathrm{E}-05 & 100 \\ 11289-107.1 & 42 & 32 & 0.78 & 126 & 9224 & 6.8 \mathrm{E}-05 & 100 \\ 11289-109.1 & 157 & 57 & 0.37 & 185 & 8999 & 1.1 \mathrm{E}-05 & 100 \\ 11289-110.1 & 49 & 39 & 0.83 & 331 & 7921 & 1.7 \mathrm{E}-04 & 50 \\ 11289-112.1 & 129 & 52 & 0.42 & 147 & 10535 & 2.9 \mathrm{E}-04 & 28 \\ 11289-113.1 & 55 & 37 & 0.70 & 151 & 9283 & 6.5 \mathrm{E}-04 & 30 \\ 11289-119.1 & 53 & 41 & 0.80 & 183 & 8922 & 2.1 \mathrm{E}-04 & 50 \\ 11289-120.1 & 53 & 38 & 0.75 & 149 & 9280 & 2.7 \mathrm{E}-04 & 45 \\ 11289-123.1 & 57 & 39 & 0.70 & 135 & 9405 & 9.3 \mathrm{E}-04 & 26 \\ 11289-125.1 & 41 & 15 & 0.38 & 201 & 7941 & 8.2 \mathrm{E}-04 & 26 \\ 11289-126.1 & 52 & 54 & 1.06 & 276 & 8457 & 3.9 \mathrm{E}-04 & 41 \\ 11289-127.1 & 195 & 128 & 0.68 & 205 & 9461 & -2.8 \mathrm{E}-05 & 71 \\ 11289-128.1 & 76 & 67 & 0.92 & 237 & 9466 & 5.2 \mathrm{E}-05 & 100 \\ 11289-129.1 & 100 & 68 & 0.70 & 129 & 7905 & 1.2 \mathrm{E}-04 & 45 \\ 11289-130.1 & 44 & 32 & 0.75 & 130 & 9553 & -8.6 \mathrm{E}-05 & 100 \\ 11289-131.1 & 67 & 29 & 0.45 & 152 & 11657 & 4.3 \mathrm{E}-04 & 38\end{array}$

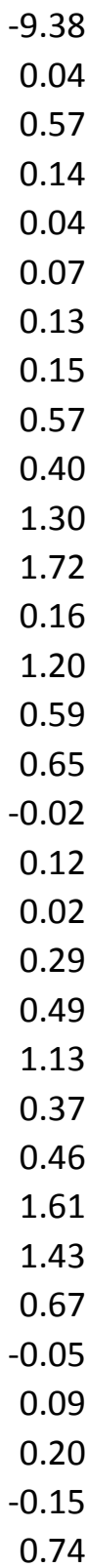

$\begin{array}{lllllllllll}24.1 & 0.346 & 6.4 & 12.942 & 3.5 & 0.4479 & 1.8 & 0.520 & 0.2096 & 3.0 & 2386\end{array}$ $\begin{array}{lllllllllll}92.2 & 0.098 & 3.8 & 18.186 & 1.5 & 0.5943 & 1.2 & 0.851 & 0.2219 & 0.8 & 3007\end{array}$ $\begin{array}{lllllllllll}31.3 & 0.283 & 3.8 & 7.336 & 2.0 & 0.3912 & 1.4 & 0.678 & 0.1360 & 1.5 & 2129\end{array}$ $\begin{array}{llllllllllll}72.7 & 0.141 & 6.5 & 14.099 & 1.4 & 0.5325 & 1.2 & 0.887 & 0.1920 & 0.6 & 2752\end{array}$ $\begin{array}{llllllllllll}76.7 & 0.098 & 3.8 & 12.136 & 1.4 & 0.4978 & 1.2 & 0.888 & 0.1768 & 0.6 & 2604\end{array}$ $\begin{array}{lllllllllll}72.1 & 0.127 & 3.4 & 16.851 & 1.4 & 0.5784 & 1.2 & 0.902 & 0.2113 & 0.6 & 2942\end{array}$ $\begin{array}{lllllllllll}86.4 & 0.420 & 1.7 & 13.584 & 1.3 & 0.5232 & 1.2 & 0.896 & 0.1883 & 0.6 & 2713\end{array}$ $\begin{array}{lllllllllll}22.1 & 0.225 & 10.6 & 7.525 & 2.1 & 0.3953 & 1.5 & 0.688 & 0.1380 & 1.5 & 2148\end{array}$ $\begin{array}{lllllllllll}39.1 & 0.101 & 7.1 & 15.077 & 1.7 & 0.5312 & 1.5 & 0.835 & 0.2058 & 1.0 & 2747\end{array}$ $\begin{array}{lllllllllll}43.1 & 0.179 & 4.1 & 13.246 & 1.7 & 0.5252 & 1.3 & 0.814 & 0.1829 & 1.0 & 2721\end{array}$ $\begin{array}{lllllllllll}13.5 & 0.143 & 15.5 & 7.241 & 3.5 & 0.3988 & 1.8 & 0.526 & 0.1317 & 3.0 & 2164\end{array}$ $\begin{array}{lllllllllll}13.8 & 0.141 & 11.8 & 6.916 & 4.3 & 0.3790 & 1.8 & 0.430 & 0.1323 & 3.9 & 2072\end{array}$ $\begin{array}{lllllllllll}102.1 & 0.130 & 3.1 & 12.912 & 1.3 & 0.5149 & 1.2 & 0.924 & 0.1819 & 0.5 & 2678\end{array}$ $\begin{array}{lllllllllll}23.8 & -0.003 & 279.4 & 17.782 & 2.1 & 0.5862 & 1.6 & 0.791 & 0.2200 & 1.3 & 2974\end{array}$ $\begin{array}{lllllllllll}9.4 & 0.174 & 9.9 & 7.467 & 3.2 & 0.3889 & 2.0 & 0.617 & 0.1393 & 2.5 & 2118\end{array}$ $\begin{array}{lllllllllll}17.9 & 0.209 & 6.1 & 8.087 & 2.4 & 0.4122 & 1.6 & 0.673 & 0.1423 & 1.7 & 2225\end{array}$ $\begin{array}{lllllllllll}70.0 & 0.127 & 3.5 & 16.952 & 1.3 & 0.5826 & 1.2 & 0.928 & 0.2111 & 0.5 & 2959\end{array}$ $\begin{array}{lllllllllll}14.9 & 0.217 & 6.1 & 7.658 & 2.4 & 0.4092 & 1.7 & 0.699 & 0.1357 & 1.7 & 2211\end{array}$ $\begin{array}{lllllllllll}76.1 & 0.100 & 3.9 & 16.492 & 1.4 & 0.5632 & 1.3 & 0.904 & 0.2124 & 0.6 & 2880\end{array}$ $\begin{array}{lllllllllll}22.4 & 0.223 & 5.6 & 15.658 & 2.2 & 0.5385 & 1.9 & 0.843 & 0.2109 & 1.2 & 2777\end{array}$ $\begin{array}{lllllllllll}63.5 & 0.102 & 7.1 & 15.950 & 1.8 & 0.5734 & 1.5 & 0.851 & 0.2017 & 0.9 & 2922\end{array}$ $\begin{array}{lllllllllll}19.2 & 0.198 & 7.2 & 7.312 & 3.1 & 0.4062 & 1.8 & 0.570 & 0.1306 & 2.6 & 2197\end{array}$ $\begin{array}{lllllllllll}18.4 & 0.250 & 5.2 & 7.724 & 2.3 & 0.4032 & 1.5 & 0.673 & 0.1390 & 1.7 & 2184\end{array}$ $\begin{array}{lllllllllll}18.6 & 0.220 & 5.6 & 7.859 & 2.4 & 0.4076 & 1.6 & 0.658 & 0.1398 & 1.8 & 2204\end{array}$ $\begin{array}{lllllllllll}18.9 & 0.193 & 8.4 & 7.168 & 4.6 & 0.3849 & 1.7 & 0.363 & 0.1351 & 4.2 & 2099\end{array}$ $\begin{array}{lllllllllll}18.5 & 0.113 & 10.7 & 14.719 & 2.4 & 0.5304 & 1.8 & 0.725 & 0.2013 & 1.7 & 2743\end{array}$ $\begin{array}{lllllllllll}17.8 & 0.311 & 5.2 & 7.670 & 2.6 & 0.3982 & 1.7 & 0.643 & 0.1397 & 2.0 & 2161\end{array}$ $\begin{array}{lllllllllll}82.5 & 0.192 & 2.8 & 11.979 & 1.5 & 0.4930 & 1.2 & 0.808 & 0.1762 & 0.9 & 2584\end{array}$ $\begin{array}{lllllllllll}26.6 & 0.252 & 4.9 & 7.826 & 2.0 & 0.4093 & 1.6 & 0.788 & 0.1387 & 1.2 & 2212\end{array}$ $\begin{array}{lllllllllll}44.8 & 0.184 & 3.9 & 13.567 & 1.6 & 0.5208 & 1.4 & 0.874 & 0.1889 & 0.8 & 2703\end{array}$ $\begin{array}{llllllllllll}14.8 & 0.206 & 7.0 & 7.698 & 2.4 & 0.3905 & 1.8 & 0.743 & 0.1430 & 1.6 & 2125\end{array}$ $\begin{array}{lllllllllll}31.7 & 0.137 & 8.7 & 15.909 & 2.3 & 0.5533 & 1.8 & 0.789 & 0.2086 & 1.4 & 2839\end{array}$

$\begin{array}{rrrr}36 & 2902 & 48 & +21 \\ 30 & 2995 & 12 & -1 \\ 25 & 2177 & 26 & +3 \\ 28 & 2760 & 10 & +0 \\ 26 & 2623 & 10 & +1 \\ 29 & 2915 & 10 & -1 \\ 27 & 2727 & 10 & +1 \\ 27 & 2203 & 27 & +3 \\ 33 & 2873 & 16 & +5 \\ 30 & 2680 & 16 & -2 \\ 34 & 2120 & 52 & -2 \\ 33 & 2129 & 68 & +3 \\ 26 & 2670 & 8 & -0 \\ 39 & 2981 & 20 & +0 \\ 36 & 2218 & 44 & +5 \\ 30 & 2255 & 30 & +2 \\ 30 & 2914 & 8 & -2 \\ 31 & 2174 & 30 & -2 \\ 30 & 2924 & 10 & +2 \\ 42 & 2913 & 19 & +6 \\ 36 & 2840 & 15 & -4 \\ 33 & 2105 & 45 & -5 \\ 29 & 2214 & 30 & +2 \\ 29 & 2225 & 31 & +1 \\ 30 & 2165 & 74 & +4 \\ 39 & 2836 & 27 & +4 \\ 30 & 2223 & 34 & +3 \\ 26 & 2618 & 15 & +2 \\ 29 & 2211 & 21 & -0 \\ 30 & 2733 & 12 & +1 \\ 32 & 2264 & 28 & +7 \\ 42 & 2894 & 23 & +2\end{array}$

https://mc06.manuscriptcentral.com/cjes-pubs 


\begin{tabular}{|c|c|c|c|c|c|c|c|c|c|c|c|c|c|c|c|c|c|c|c|c|c|c|c|}
\hline $11289-132.1$ & 95 & 62 & 0.68 & 161 & 10559 & 5.3E-05 & 100 & 0.09 & 33.6 & 0.182 & 5.7 & 7.643 & 2.0 & 0.4124 & 1.6 & 0.783 & 0.1344 & 1.3 & 2226 & 30 & 2156 & 22 & -4 \\
\hline 11289-133.1 & 54 & 48 & 0.92 & 73 & 8970 & $2.4 \mathrm{E}-04$ & 50 & 0.41 & 24.2 & 0.271 & 5.3 & 13.307 & 2.2 & 0.5232 & 1.8 & 0.797 & 0.1844 & 1.3 & 2713 & 39 & 2693 & 22 & -1 \\
\hline 11289-134.1 & 69 & 63 & 0.94 & 286 & 9403 & $1.3 \mathrm{E}-04$ & 71 & 0.23 & 24.6 & 0.288 & 5.2 & 8.153 & 2.3 & 0.4121 & 1.7 & 0.744 & 0.1435 & 1.5 & 2224 & 32 & 2270 & 26 & +2 \\
\hline 11289-135.1 & 132 & 116 & 0.91 & 349 & 9952 & $1.5 \mathrm{E}-04$ & 45 & 0.26 & 45.7 & 0.236 & 3.9 & 7.663 & 1.7 & 0.4041 & 1.4 & 0.789 & 0.1376 & 1.1 & 2188 & 25 & 2197 & 18 & +0 \\
\hline 11289-137.1 & 204 & 110 & 0.56 & 209 & 9293 & 9.7E-05 & 41 & 0.17 & 87.3 & 0.156 & 3.5 & 11.957 & 1.6 & 0.4987 & 1.3 & 0.796 & 0.1739 & 1.0 & 2608 & 27 & 2595 & 16 & -1 \\
\hline 11289-138.1 & 119 & 51 & 0.44 & 68 & 9117 & $3.2 \mathrm{E}-04$ & 30 & 0.55 & 66.4 & 0.111 & 6.3 & 23.755 & 1.7 & 0.6509 & 1.5 & 0.885 & 0.2647 & 0.8 & 3232 & 38 & 3275 & 12 & +2 \\
\hline 11289-141.1 & 52 & 22 & 0.43 & 122 & 8505 & $4.5 \mathrm{E}-04$ & 38 & 0.78 & 24.6 & 0.115 & 9.9 & 16.322 & 2.4 & 0.5496 & 1.9 & 0.790 & 0.2154 & 1.4 & 2823 & 43 & 2947 & 23 & +5 \\
\hline 11289-142.1 & 85 & 64 & 0.77 & 191 & 9212 & 5.7E-04 & 27 & 0.98 & 37.6 & 0.212 & 5.4 & 12.709 & 5.7 & 0.5157 & 1.6 & 0.275 & 0.1787 & 5.5 & 2681 & 35 & 2641 & 91 & -2 \\
\hline 11289-143.1 & 62 & 49 & 0.82 & 198 & 9676 & $2.2 \mathrm{E}-04$ & 58 & 0.37 & 20.9 & 0.215 & 10.3 & 7.618 & 2.4 & 0.3939 & 1.7 & 0.691 & 0.1403 & 1.8 & 2141 & 31 & 2231 & 30 & +5 \\
\hline 11289-145.1 & 77 & 14 & 0.19 & 67 & 11326 & 7.9E-04 & 23 & 1.37 & 34.5 & 0.031 & 27.7 & 14.324 & 2.2 & 0.5219 & 1.6 & 0.747 & 0.1991 & 1.5 & 2707 & 36 & 2819 & 24 & +5 \\
\hline 11289-148.1 & 55 & 35 & 0.66 & 150 & 10315 & $3.5 \mathrm{E}-04$ & 50 & 0.60 & 18.7 & 0.185 & 8.2 & 7.543 & 2.9 & 0.3963 & 1.8 & 0.638 & 0.1380 & 2.2 & 2152 & 34 & 2203 & 39 & +3 \\
\hline 11289-149.1 & 86 & 57 & 0.68 & 242 & 9237 & 1.1E-04 & 58 & 0.20 & 43.4 & 0.194 & 4.9 & 18.597 & 1.8 & 0.5886 & 1.6 & 0.872 & 0.2291 & 0.9 & 2984 & 38 & 3046 & 14 & +3 \\
\hline 11289-150.1 & 108 & 86 & 0.83 & 161 & 8868 & 5.7E-04 & 24 & 0.99 & 47.1 & 0.217 & 4.8 & 13.086 & 1.9 & 0.5096 & 1.5 & 0.770 & 0.1862 & 1.2 & 2655 & 32 & 2709 & 20 & +2 \\
\hline 11289-153.1 & 128 & 31 & 0.25 & 73 & 11692 & $2.5 \mathrm{E}-05$ & 100 & 0.04 & 56.5 & 0.069 & 6.6 & 13.689 & 1.5 & 0.5145 & 1.4 & 0.890 & 0.1930 & 0.7 & 2676 & 30 & 2768 & 12 & +4 \\
\hline 11289-154.1 & 187 & 89 & 0.49 & 193 & 11834 & $3.3 \mathrm{E}-04$ & 33 & 0.57 & 78.7 & 0.113 & 7.2 & 11.646 & 1.9 & 0.4900 & 1.5 & 0.784 & 0.1724 & 1.2 & 2571 & 32 & 2581 & 20 & +0 \\
\hline 11289-155.1 & 107 & 72 & 0.70 & 245 & 10070 & $2.8 \mathrm{E}-05$ & 100 & 0.05 & 52.9 & 0.201 & 3.9 & 17.439 & 1.6 & 0.5746 & 1.4 & 0.894 & 0.2201 & 0.7 & 2927 & 34 & 2981 & 12 & +2 \\
\hline \multicolumn{24}{|c|}{ SAMPLE 2: Granodiorite sill 14PBA-027D1; $11291(\overline{66.34086,-96.56123)}$} \\
\hline 11291-047.2 & 780 & 205 & 0.27 & 110 & 11442 & $1.3 \mathrm{E}-05$ & 41 & 0.02 & 221.4 & 0.080 & 1.8 & 5.123 & 0.9 & 0.3302 & 0.8 & 0.957 & 0.1125 & 0.3 & 1840 & 14 & 1840 & 5 & +0 \\
\hline 11291-047.1 & 822 & 214 & 0.27 & 127 & 11767 & --- & --- & 0.00 & 234.8 & 0.078 & 1.7 & 5.182 & 0.9 & 0.3325 & 0.8 & 0.963 & 0.1130 & 0.2 & 1850 & 14 & 1849 & 4 & -0 \\
\hline 11291-044.2 & 746 & 139 & 0.19 & 41 & 13273 & $-2.5 \mathrm{E}-06$ & 100 & 0.00 & 205.8 & 0.057 & 2.2 & 5.008 & 0.9 & 0.3210 & 0.9 & 0.955 & 0.1132 & 0.3 & 1795 & 13 & 1851 & 5 & +3 \\
\hline 11291-041.1 & 984 & 285 & 0.30 & 119 & 11381 & $3.5 \mathrm{E}-06$ & 71 & 0.01 & 283.4 & 0.089 & 1.5 & 5.238 & 0.9 & 0.3353 & 0.8 & 0.968 & 0.1133 & 0.2 & 1864 & 14 & 1853 & 4 & -1 \\
\hline 11291-044.1 & 932 & 171 & 0.19 & 44 & 12924 & $-1.8 \mathrm{E}-06$ & 100 & 0.00 & 265.5 & 0.056 & 1.9 & 5.201 & 0.9 & 0.3316 & 0.9 & 0.972 & 0.1138 & 0.2 & 1846 & 15 & 1860 & 4 & +1 \\
\hline 11291-058.1 & 3005 & 271 & 0.09 & 573 & 15810 & $1.4 \mathrm{E}-03$ & 2 & 2.50 & 996.7 & 0.053 & 2.5 & 7.257 & 1.3 & 0.3861 & 1.3 & 0.971 & 0.1363 & 0.3 & 2105 & 23 & 2181 & 5 & +4 \\
\hline 11291-002.1 & 68 & 25 & 0.38 & 131 & 10264 & --- & --- & 0.00 & 25.2 & 0.108 & 4.5 & 9.120 & 1.4 & 0.4342 & 1.2 & 0.860 & 0.1523 & 0.7 & 2325 & 24 & 2372 & 13 & +2 \\
\hline 11291-003.1 & 174 & 56 & 0.33 & 121 & 11594 & $1.5 \mathrm{E}-05$ & 71 & 0.03 & 66.0 & 0.095 & 3.0 & 9.860 & 1.1 & 0.4418 & 1.0 & 0.926 & 0.1619 & 0.4 & 2359 & 20 & 2475 & 7 & +6 \\
\hline 11291-064.1 & 795 & 74 & 0.10 & 220 & 15085 & $7.5 \mathrm{E}-06$ & 45 & 0.01 & 322.0 & 0.028 & 4.0 & 10.816 & 1.3 & 0.4713 & 0.8 & 0.648 & 0.1664 & 1.0 & 2489 & 18 & 2522 & 17 & +2 \\
\hline 11291-014.1 & 936 & 399 & 0.44 & 367 & 11795 & $6.1 \mathrm{E}-06$ & 45 & 0.01 & 381.3 & 0.127 & 2.9 & 10.905 & 0.9 & 0.4745 & 0.8 & 0.982 & 0.1667 & 0.2 & 2503 & 17 & 2525 & 3 & +1 \\
\hline 11291-017.1 & 663 & 69 & 0.11 & 219 & 14079 & $2.5 \mathrm{E}-05$ & 27 & 0.04 & 272.3 & 0.034 & 4.2 & 11.039 & 2.2 & 0.4781 & 2.0 & 0.922 & 0.1674 & 0.9 & 2519 & 42 & 2532 & 14 & +1 \\
\hline 11291-007.1 & 848 & 218 & 0.27 & 266 & 12782 & $6.9 \mathrm{E}-06$ & 45 & 0.01 & 352.3 & 0.076 & 1.4 & 11.358 & 0.9 & 0.4838 & 0.8 & 0.980 & 0.1703 & 0.2 & 2544 & 18 & 2560 & 3 & +1 \\
\hline $11291-032.2$ & 364 & 215 & 0.61 & 203 & 10333 & $1.2 \mathrm{E}-05$ & 50 & 0.02 & 149.8 & 0.170 & 1.4 & 11.290 & 0.9 & 0.4797 & 0.9 & 0.962 & 0.1707 & 0.3 & 2526 & 19 & 2564 & 4 & +2 \\
\hline 11291-032.1 & 330 & 72 & 0.23 & 412 & 13011 & $2.0 \mathrm{E}-05$ & 41 & 0.04 & 139.2 & 0.064 & 2.4 & 11.554 & 2.1 & 0.4909 & 1.1 & 0.530 & 0.1707 & 1.8 & 2574 & 23 & 2565 & 29 & -0 \\
\hline 11291-006.1 & 981 & 264 & 0.28 & 269 & 13183 & $6.9 \mathrm{E}-06$ & 41 & 0.01 & 413.8 & 0.080 & 1.2 & 11.569 & 0.9 & 0.4912 & 0.8 & 0.980 & 0.1708 & 0.2 & 2576 & 18 & 2565 & 3 & -1 \\
\hline
\end{tabular}




$\begin{array}{lrrrrrrr}11291-040.1 & 352 & 101 & 0.30 & 268 & 11326 & 1.3 \mathrm{E}-05 & 50 \\ 11291-028.1 & 447 & 115 & 0.27 & 235 & 12625 & 3.8 \mathrm{E}-05 & 26 \\ 11291-001.1 & 230 & 92 & 0.41 & 170 & 10257 & 3.6 \mathrm{E}-05 & 38 \\ 11291-049.1 & 756 & 366 & 0.50 & 393 & 11816 & -1.5 \mathrm{E}-06 & 100 \\ 11291-004.1 & 218 & 74 & 0.35 & 137 & 11466 & 2.7 \mathrm{E}-05 & 45 \\ 11291-037.1 & 216 & 90 & 0.43 & 184 & 10536 & -5.3 \mathrm{E}-06 & 100 \\ \text { SAMPLE 4: Arkosic sandstone } 12 \text { PBAB-19A; 11290 (66.60179, } & -95.90890) \\ 11290-002.1 & 895 & 513 & 0.59 & 444 & 9308 & 3.3 \mathrm{E}-05 & 50 \\ 11290-004.1 & 1616 & 774 & 0.49 & 290 & 12740 & 1.1 \mathrm{E}-05 & 71 \\ 11290-004.1 .2 & 1513 & 716 & 0.49 & 271 & 13295 & 6.4 \mathrm{E}-05 & 35 \\ 11290-004.2 & 505 & 307 & 0.63 & 175 & 11340 & 1.6 \mathrm{E}-05 & 100 \\ 11290-004.2 .2 & 536 & 317 & 0.61 & 169 & 10813 & 7.4 \mathrm{E}-05 & 45 \\ 11290-006.1 & 271 & 224 & 0.85 & 214 & 10237 & 3.9 \mathrm{E}-04 & 23 \\ 11290-009.1 & 2156 & 77 & 0.04 & 119 & 13106 & -3.9 \mathrm{E}-06 & 100 \\ 11290-009.1 .2 & 2245 & 86 & 0.04 & 114 & 13332 & 4.4 \mathrm{E}-05 & 24 \\ 11290-009.1 .3 & 1607 & 139 & 0.09 & 83 & 9368 & 1.2 \mathrm{E}-05 & 58 \\ 11290-009.2 & 1404 & 125 & 0.09 & 77 & 10737 & 1.8 \mathrm{E}-05 & 35 \\ 11290-015.1 & 406 & 244 & 0.62 & 85 & 9692 & 1.9 \mathrm{E}-04 & 30 \\ 11290-017.1 & 1004 & 369 & 0.38 & 311 & 7979 & 1.5 \mathrm{E}-04 & 21 \\ 11290-018.1 & 1007 & 399 & 0.41 & 183 & 11685 & 4.8 \mathrm{E}-05 & 45 \\ 11290-026.1 & 1588 & 519 & 0.34 & 543 & 10062 & 4.2 \mathrm{E}-05 & 50 \\ 11290-028.1 & 108 & 35 & 0.34 & 148 & 10536 & -2.2 \mathrm{E}-04 & 71 \\ 11290-034.1 & 2107 & 492 & 0.24 & 251 & 10605 & 7.8 \mathrm{E}-05 & 32 \\ 11290-035.1 & 126 & 173 & 1.42 & 104 & 9723 & 1.5 \mathrm{E}-03 & 28 \\ 11290-037.1 & 1205 & 521 & 0.45 & 192 & 10731 & 3.5 \mathrm{E}-05 & 50 \\ 11290-039.1 & 643 & 352 & 0.56 & 351 & 9428 & --- & --- \\ 11290-041.1 & 568 & 490 & 0.89 & 166 & 10409 & -3.1 \mathrm{E}-05 & 71 \\ 11290-042.1 & 1269 & 564 & 0.46 & 411 & 11945 & 6.8 \mathrm{E}-05 & 50 \\ 11290-046.1 & 1820 & 72 & 0.04 & 442 & 13952 & 1.1 \mathrm{E}-05 & 45 \\ 11290-047.1 & 414 & 186 & 0.46 & 184 & 8759 & 4.0 \mathrm{E}-05 & 58 \\ 11290-048.1 & 226 & 309 & 1.41 & 313 & 9550 & 4.1 \mathrm{E}-04 & 45 \\ 11290-049.1 & 830 & 301 & 0.37 & 267 & 11332 & 6.1 \mathrm{E}-06 & 100\end{array}$

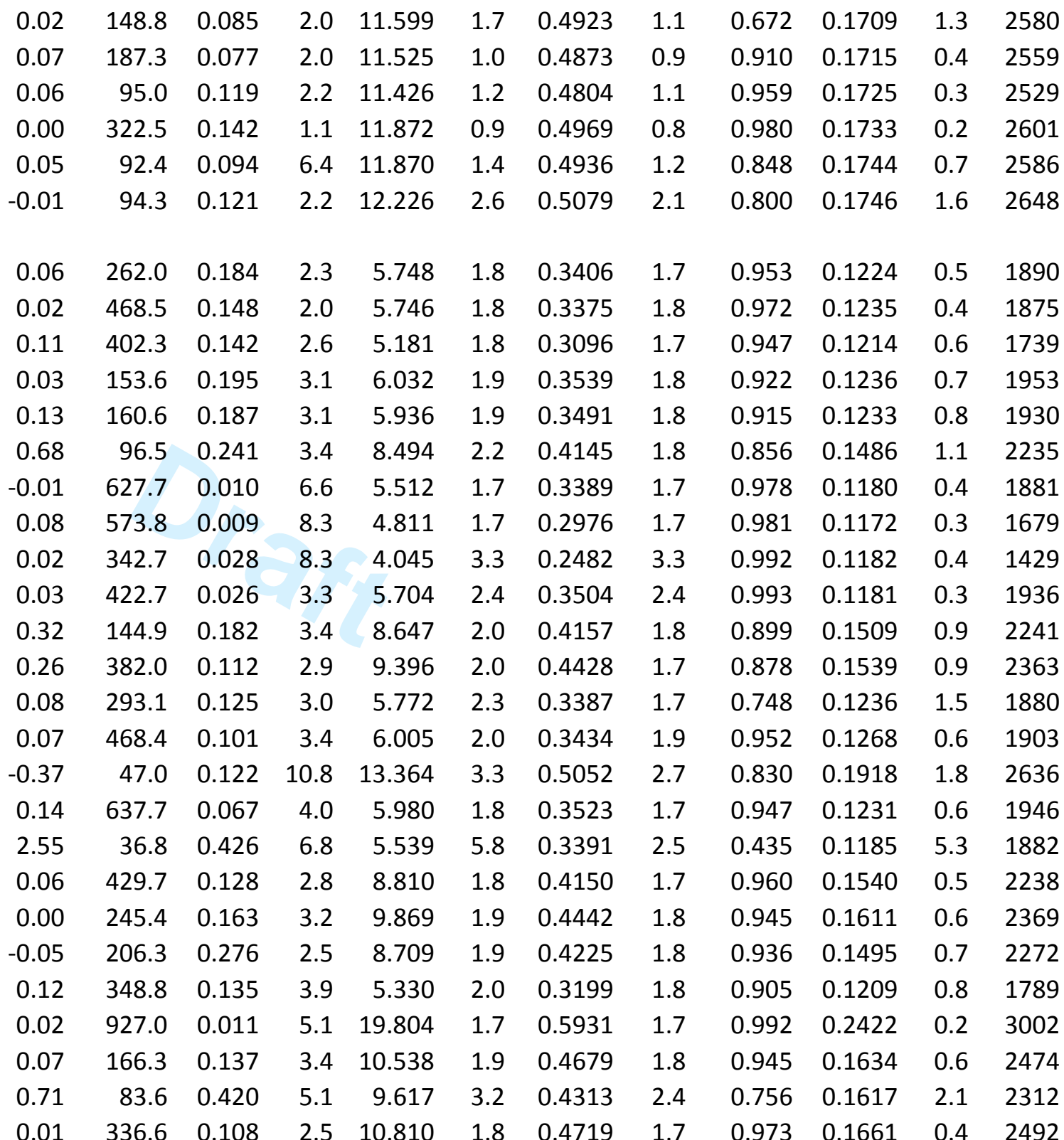

$\begin{array}{rrrr}24 & 2566 & 21 & -1 \\ 19 & 2573 & 7 & +1 \\ 24 & 2582 & 6 & +2 \\ 18 & 2589 & 3 & -1 \\ 25 & 2600 & 12 & +1 \\ 45 & 2602 & 26 & -2 \\ & & & \\ 28 & 1991 & 10 & +6 \\ 29 & 2007 & 8 & +8 \\ 26 & 1976 & 10 & +14 \\ 30 & 2009 & 13 & +3 \\ 29 & 2005 & 14 & +4 \\ 35 & 2330 & 19 & +5 \\ 27 & 1926 & 6 & +3 \\ 24 & 1914 & 6 & +14 \\ 42 & 1929 & 7 & +29 \\ 40 & 1927 & 5 & -1 \\ 35 & 2356 & 15 & +6 \\ 34 & 2390 & 16 & +1 \\ 28 & 2009 & 27 & +7 \\ 31 & 2054 & 11 & +8 \\ 59 & 2758 & 30 & +5 \\ 29 & 2002 & 10 & +3 \\ 42 & 1933 & 94 & +3 \\ 33 & 2390 & 9 & +8 \\ 36 & 2468 & 10 & +5 \\ 34 & 2340 & 12 & +3 \\ 28 & 1969 & 15 & +10 \\ 40 & 3134 & 3 & +5 \\ 36 & 2491 & 10 & +1 \\ 47 & 2474 & 36 & +8 \\ 35 & 2519 & 7 & +1 \\ & & & \end{array}$




$\begin{array}{lrrrrrrr}11290-050.1 & 339 & 236 & 0.72 & 136 & 9344 & 4.5 \mathrm{E}-04 & 21 \\ 11290-050.1 .2 & 378 & 250 & 0.68 & 130 & 10278 & 4.6 \mathrm{E}-04 & 21 \\ 11290-050.2 & 790 & 641 & 0.84 & 259 & 9407 & 7.3 \mathrm{E}-05 & 32 \\ 11290-050.2 .2 & 603 & 467 & 0.80 & 142 & 5538 & 1.4 \mathrm{E}-04 & 22 \\ 11290-051.1 & 1390 & 234 & 0.17 & 120 & 12117 & 3.9 \mathrm{E}-05 & 32 \\ 11290-052.1 & 150 & 24 & 0.17 & 146 & 10674 & 1.9 \mathrm{E}-04 & 41 \\ 11290-057.1 & 858 & 381 & 0.46 & 228 & 9098 & 2.0 \mathrm{E}-05 & 58 \\ 11290-062.1 & 6416 & 1496 & 0.24 & 817 & 12414 & 4.3 \mathrm{E}-05 & 25 \\ 11290-062.2 & 4434 & 793 & 0.18 & 505 & 12602 & 1.6 \mathrm{E}-05 & 32 \\ 11290-062.2 .2 & 4228 & 740 & 0.18 & 390 & 10087 & 1.0 \mathrm{E}-05 & 41 \\ 11290-063.1 & 2435 & 1383 & 0.59 & 322 & 11276 & 2.2 \mathrm{E}-06 & 100 \\ 11290-063.1 .3 & 2195 & 1243 & 0.58 & 251 & 9399 & --- & --- \\ 11290-063.1 .3 \mathrm{~d} & 2060 & 1147 & 0.58 & 206 & 7572 & 1.3 \mathrm{E}-05 & 50 \\ 11290-064.1 & 1375 & 503 & 0.38 & 260 & 11997 & 6.2 \mathrm{E}-06 & 71 \\ 11290-065.1 & 730 & 347 & 0.49 & 202 & 10572 & 3.3 \mathrm{E}-05 & 41 \\ 11290-066.1 & 736 & 368 & 0.52 & 370 & 10271 & 3.0 \mathrm{E}-05 & 50 \\ 11290-067.1 & 993 & 388 & 0.40 & 208 & 12293 & 2.4 \mathrm{E}-05 & 50 \\ 11290-069.1 & 1278 & 504 & 0.41 & 251 & 11575 & 4.7 \mathrm{E}-06 & 100 \\ 11290-070.1 & 570 & 308 & 0.56 & 351 & 8795 & 2.3 \mathrm{E}-05 & 45 \\ 11290-071.1 & 1244 & 1052 & 0.87 & 409 & 10147 & --- & --- \\ 11290-075.1 & 469 & 296 & 0.65 & 194 & 8787 & 4.7 \mathrm{E}-05 & 41 \\ 11290-076.1 & 406 & 281 & 0.72 & 137 & 10600 & 3.2 \mathrm{E}-05 & 71 \\ 11290-076.2 & 1157 & 424 & 0.38 & 226 & 14132 & 4.0 \mathrm{E}-05 & 50 \\ 11290-076.2 .2 & 1268 & 457 & 0.37 & 212 & 13495 & 4.6 \mathrm{E}-05 & 45 \\ 11290-078.1 & 1436 & 656 & 0.47 & 306 & 11219 & 9.4 \mathrm{E}-06 & 71 \\ 11290-081.1 & 792 & 523 & 0.68 & 330 & 9287 & 6.4 \mathrm{E}-05 & 33 \\ 11290-083.1 & 952 & 507 & 0.55 & 304 & 10291 & 1.9 \mathrm{E}-05 & 50 \\ 11290-085.1 & 1112 & 429 & 0.40 & 240 & 11303 & 6.0 \mathrm{E}-05 & 32 \\ 11290-088.1 & 1255 & 693 & 0.57 & 269 & 11450 & 6.9 \mathrm{E}-05 & 29 \\ 11290-091.1 & 784 & 240 & 0.32 & 288 & 9859 & 7.2 \mathrm{E}-05 & 32 \\ 11290-092.1 & 442 & 222 & 0.52 & 256 & 9834 & 1.4 \mathrm{E}-04 & 32 \\ 11290-093.1 & 727 & 358 & 0.51 & 313 & 10218 & 4.1 \mathrm{E}-05 & 45\end{array}$

\begin{tabular}{|c|c|c|c|c|c|c|c|c|c|c|c|}
\hline 78 & 87.9 & 0.173 & 4.7 & 4.909 & 2.3 & 0.3019 & 1.8 & 0.788 & 0.1179 & 4 & 1701 \\
\hline 0.80 & 84.6 & 0.163 & 4.6 & 4.289 & 2.3 & 0.2606 & 1.8 & 0.780 & 0.1194 & 1.4 & 1493 \\
\hline 0.13 & 196.1 & 0.244 & 2.0 & 4.774 & 2.7 & 0.2889 & 2.6 & 0.976 & 0.1199 & 0.6 & 1636 \\
\hline 0.24 & 138.1 & 0.240 & 1.8 & 4.365 & 3.2 & 0.2666 & 3.2 & 0.983 & 0.1187 & 0.6 & 1524 \\
\hline 0.07 & 419.8 & 0.046 & 3.3 & 6.012 & 1.9 & 0.3515 & 1.8 & 0.940 & 0.1241 & 0.6 & 1942 \\
\hline 0.32 & 59.5 & 0.058 & 9.5 & 10.448 & 2.2 & 0.4622 & 2.0 & 0.876 & 0.1640 & 1.1 & 2449 \\
\hline 0.04 & 258.0 & 0.128 & 2.4 & 5.954 & 1.8 & 0.3500 & 1.7 & 0.962 & 0.1234 & 0.5 & 1935 \\
\hline 0.07 & 1781.4 & 0.068 & 2.2 & 5.276 & 1.9 & 0.3232 & 1.8 & 0.985 & 0.1184 & 0.3 & 1805 \\
\hline 0.03 & 1218.0 & 0.055 & 1.8 & 5.253 & 1.7 & 0.3198 & 1.7 & 0.990 & 0.1191 & 0.2 & 1789 \\
\hline 0.02 & 1056.6 & 0.055 & 1.9 & 4.787 & 1.8 & 0.2909 & 1.8 & 0.991 & 0.1193 & 0.2 & 1646 \\
\hline 0.00 & 700.0 & 0.175 & 1.2 & 5.560 & 2.1 & 0.3346 & 2.1 & 0.992 & 0.1205 & 0.3 & 1861 \\
\hline 0.00 & 569.9 & 0.175 & 1.5 & 5.053 & 1.8 & 0.3023 & 1.8 & 0.982 & 0.1212 & 0.3 & 1703 \\
\hline 0.02 & 486.1 & 0.169 & 1.5 & 4.551 & 1.7 & 0.2747 & 1.7 & 0.980 & 0.1202 & 0.3 & 1564 \\
\hline 0.01 & 473.3 & 0.109 & 1.8 & 7.909 & 2.2 & 0.4008 & 2.0 & 0.933 & 0.1431 & 0.8 & 2173 \\
\hline 0.06 & 281.7 & 0.142 & 2.1 & 10.083 & 2.2 & 0.4490 & 2.2 & 0.984 & 0.1629 & 0.4 & 2391 \\
\hline 0.05 & 219.8 & 0.147 & 2.4 & 5.864 & 1.9 & 0.3476 & 1.9 & 0.963 & 0.1223 & 0.5 & 1923 \\
\hline 0.04 & 287.3 & 0.118 & 2.4 & 5.595 & 1.9 & 0.3368 & 1.7 & 0.903 & 0.1205 & 0.8 & 1871 \\
\hline 0.01 & 385.8 & 0.119 & 2.1 & 5.939 & 1.7 & 0.3514 & 1.7 & 0.974 & 0.1226 & 0.4 & 1941 \\
\hline 0.04 & 380.2 & 0.148 & 1.9 & 39.766 & 2.6 & 0.7766 & 1.7 & 0.673 & 0.3714 & 1.9 & 3705 \\
\hline 0.00 & 370.9 & 0.254 & 1.6 & 5.843 & 1.7 & 0.3470 & 1.7 & 0.971 & 0.1221 & 0.4 & 1920 \\
\hline 0.08 & 270.4 & 0.171 & 2.4 & 25.304 & 1.9 & 0.6706 & 1.8 & 0.907 & 0.2737 & 0.8 & 3308 \\
\hline 0.06 & 104.8 & 0.201 & 3.0 & 4.978 & 1.9 & 0.3007 & 1.8 & 0.914 & 0.1201 & 0.8 & 1695 \\
\hline 0.07 & 295.8 & 0.102 & 3.4 & 4.958 & 1.8 & 0.2976 & 1.7 & 0.941 & 0.1208 & 0.6 & 1679 \\
\hline 0.08 & 302.7 & 0.102 & 3.3 & 4.614 & 1.8 & 0.2780 & 1.7 & 0.945 & 0.1204 & 0.6 & 1581 \\
\hline 0.02 & 409.9 & 0.137 & 1.9 & 5.632 & 1.7 & 0.3322 & 1.7 & 0.974 & 0.1230 & 0.4 & 1849 \\
\hline 0.11 & 230.6 & 0.204 & 2.0 & 5.639 & 1.8 & 0.3389 & 1.7 & 0.953 & 0.1207 & 0.5 & 1882 \\
\hline 0.03 & 399.5 & 0.162 & 1.8 & 12.013 & 1.7 & 0.4887 & 1.7 & 0.979 & 0.1783 & 0.3 & 2565 \\
\hline 0.10 & 401.4 & 0.116 & 2.5 & 9.535 & 1.9 & 0.4203 & 1.8 & 0.975 & 0.1645 & 0.4 & 2262 \\
\hline 0.12 & 365.7 & 0.170 & 2.0 & 5.614 & 1.8 & 0.3391 & 1.7 & 0.960 & 0.1201 & 0.5 & 1882 \\
\hline 0.13 & 292.9 & 0.090 & 3.1 & 9.436 & 1.8 & 0.4352 & 1.7 & 0.963 & 0.1573 & 0.5 & 2329 \\
\hline 0.25 & 134.2 & 0.152 & 3.5 & 5.969 & 2.0 & 0.3534 & 1.8 & 0.901 & 0.1225 & 0.8 & 1951 \\
\hline .07 & 231.1 & 0.140 & 2.6 & 6.597 & 1.8 & 0.3703 & 1.7 & 0.953 & 0.1292 & 0.5 & 2031 \\
\hline
\end{tabular}

$\begin{array}{rrrr}27 & 1925 & 25 & +13 \\ 24 & 1947 & 25 & +26 \\ 38 & 1954 & 10 & +18 \\ 43 & 1937 & 11 & +24 \\ 30 & 2015 & 11 & +4 \\ 40 & 2497 & 18 & +2 \\ 28 & 2006 & 9 & +4 \\ 29 & 1932 & 6 & +8 \\ 26 & 1943 & 4 & +9 \\ 26 & 1946 & 4 & +17 \\ 33 & 1964 & 5 & +6 \\ 26 & 1974 & 6 & +16 \\ 23 & 1959 & 6 & +23 \\ 38 & 2265 & 14 & +5 \\ 44 & 2486 & 7 & +5 \\ 31 & 1991 & 9 & +4 \\ 27 & 1964 & 14 & +5 \\ 28 & 1994 & 7 & +3 \\ 48 & 3797 & 29 & +3 \\ 28 & 1987 & 7 & +4 \\ 46 & 3327 & 13 & +1 \\ 26 & 1957 & 14 & +15 \\ 25 & 1969 & 11 & +17 \\ 24 & 1962 & 11 & +22 \\ 27 & 2000 & 7 & +9 \\ 28 & 1966 & 10 & +5 \\ 36 & 2637 & 6 & +3 \\ 35 & 2503 & 7 & +11 \\ 28 & 1957 & 9 & +4 \\ 34 & 2426 & 8 & +5 \\ 30 & 1993 & 15 & +2 \\ 30 & 2087 & 10 & +3\end{array}$

https://mc06.manuscriptcentral.com/cjes-pubs 


\begin{tabular}{|c|c|c|c|c|c|c|c|c|c|c|c|c|c|c|c|c|c|c|c|c|c|c|c|}
\hline $11290-094.1$ & 2441 & 2164 & 0.92 & 363 & 11981 & $2.0 \mathrm{E}-05$ & 35 & 0.04 & 750.7 & 0.270 & 1.0 & 6.057 & 1.7 & 0.3580 & 1.7 & 0.984 & 0.1227 & 0.3 & 1973 & 28 & 1996 & 5 & +1 \\
\hline 3 & 310 & 140 & 0.47 & 137 & 9609 & $9.3 \mathrm{E}-05$ & 45 & 0.16 & 131.2 & 0.134 & 4.2 & 11.461 & 2.0 & 0.4926 & 1.8 & 0.923 & 0.1687 & 0.8 & 2582 & 39 & 2545 & 13 & -2 \\
\hline 1290-100.1 & 519 & 237 & 0.47 & 136 & 10495 & 5.5E-05 & 41 & 0.10 & 192.0 & 0.134 & 2.9 & 9.708 & 1.8 & 0.4308 & 1.7 & 0.958 & 0.1634 & 0.5 & 2309 & 34 & 2492 & 9 & +9 \\
\hline
\end{tabular}

Spot name follows the convention $x-y . z$; where $x=$ sample number, $y=$ grain number and $z=$ spot number. Multiple analyses in an individual spot are labelled as $x-y . z . z$ Uncertainties reported at $1 \sigma \%$ and are calculated by numerical propagation of all known sources of error using Squid version 2.5 . Errors in ages are $1 \sigma$ absolute in Ma. f206 ${ }^{204}$ refers to mole fraction of total ${ }^{206} \mathrm{~Pb}$ that is due to common $\mathrm{Pb}$, calculated using the ${ }^{204} \mathrm{~Pb}$-method; common $\mathrm{Pb}$ composition used is the surface blank $\left({ }^{204} \mathrm{~Pb} /{ }^{206} \mathrm{~Pb}: 0.05770 ;{ }^{207} \mathrm{~Pb} /{ }^{206} \mathrm{~Pb}: 0.89500 ;{ }^{208} \mathrm{~Pb} /{ }^{206} \mathrm{~Pb}: 2.13840\right)$

* refers to radiogenic $\mathrm{Pb}$ (corrected for common $\mathrm{Pb}$ )

Discordance relative to origin $=100 *\left(1-\left({ }^{206} \mathrm{~Pb} /{ }^{238} \mathrm{U}\right.\right.$ age $) /\left({ }^{207} \mathrm{~Pb} /{ }^{206} \mathrm{~Pb}\right.$ age $\left.)\right)$

Calibration standard 6266; $\mathrm{U}=910 \mathrm{ppm} ; \mathrm{Age}=559 \mathrm{Ma} ;{ }^{206} \mathrm{~Pb} /{ }^{238} \mathrm{U}=0.09059$

Th/U calibration: $\mathrm{F}=0.03900 * \mathrm{UO}+0.85600$ 
Table 2. Zircon U-Pb isotopic data for pegmatitic gabbro sill from the lower Montresor group (66.34089; -96.56443)

\begin{tabular}{|c|c|c|c|c|c|c|c|c|c|c|c|c|c|c|c|c|c|c|c|}
\hline \multirow[b]{2}{*}{ Fraction } & \multirow[b]{2}{*}{ Description } & \multirow[b]{2}{*}{$\underset{(p p m)}{U}$} & \multirow[b]{2}{*}{$\begin{array}{l}\mathrm{Pb}^{\top} \\
(\mathrm{pg})\end{array}$} & \multirow[b]{2}{*}{$\begin{array}{l}\mathrm{Pb}_{\mathrm{c}} \\
(\mathrm{pg})\end{array}$} & \multirow[b]{2}{*}{$\mathrm{Th} / \mathrm{U}$} & \multirow[b]{2}{*}{$\begin{array}{l}{ }^{206} \mathrm{~Pb} / \\
{ }^{204} \mathrm{~Pb}\end{array}$} & \multirow[b]{2}{*}{$\begin{array}{c}{ }^{206} \mathrm{~Pb} / \\
{ }^{238} \mathrm{U}\end{array}$} & \multirow[b]{2}{*}{ $\pm 2 \sigma$} & \multirow[b]{2}{*}{$\begin{array}{c}{ }^{207} \mathrm{~Pb} / \\
{ }^{235} \mathrm{U}\end{array}$} & \multirow[b]{2}{*}{ $\pm 2 \sigma$} & \multirow[b]{2}{*}{$\begin{array}{c}{ }^{207} \mathrm{~Pb} / \\
{ }^{206} \mathrm{~Pb}\end{array}$} & \multirow[b]{2}{*}{ $\pm 2 \sigma$} & \multicolumn{5}{|c|}{ Ages (Ma) } & \multirow[b]{2}{*}{ $\pm 2 \sigma$} & \multirow[b]{2}{*}{$\begin{array}{c}\text { Disc. } \\
(\%)\end{array}$} \\
\hline & & & & & & & & & & & & & $\begin{array}{c}{ }^{206} \mathrm{~Pb} / \\
{ }^{238} \mathrm{U}\end{array}$ & $\pm 2 \sigma$ & $\begin{array}{l}{ }^{207} \mathrm{~Pb} / \\
{ }^{235} \mathrm{U}\end{array}$ & $\pm 2 \sigma$ & $\begin{array}{l}{ }^{207} \mathrm{~Pb} / \\
{ }^{206} \mathrm{~Pb}\end{array}$ & & \\
\hline \multicolumn{20}{|c|}{ 12PBA-B017E Pegmatitic gabbro sill, lower Montresor group. } \\
\hline $\mathrm{Z1}$ & $12: 1 \mathrm{clr}, \mathrm{cls} \mathrm{fl} \mathrm{pr}$ & 82 & 19.38 & 0.34 & 0.705 & 3092 & 0.508485 & 0.002144 & 13.04336 & 0.05989 & 0.186041 & 0.000240 & 2650.2 & 9.2 & 2682.8 & 4.3 & 2707.5 & 2.1 & 2.6 \\
\hline $\mathrm{Z2}$ & $12: 1 \mathrm{clr}, \mathrm{cls}$, sharp pr & 33 & 5.30 & 0.65 & 0.575 & 493 & 0.374357 & 0.003184 & 6.51751 & 0.08742 & 0.126268 & 0.001124 & 2049.9 & 14.9 & 2048.3 & 11.8 & 2046.7 & 15.8 & -0.2 \\
\hline Z3 & $12: 1 \mathrm{sm}, \mathrm{clr}, \mathrm{cls}, \mathrm{sl}$ rnd & 83 & 25.77 & 1.67 & 0.883 & 823 & 0.488028 & 0.001562 & 12.15297 & 0.06632 & 0.180608 & 0.000630 & 2562.1 & 6.8 & 2616.3 & 5.1 & 2658.5 & 5.8 & 4.4 \\
\hline Z4 & $13: 1 \mathrm{sl}$ irreg clr cls pr & 97 & 49.36 & 4.23 & 0.616 & 667 & 0.440744 & 0.001171 & 10.18466 & 0.06497 & 0.167594 & 0.000785 & 2354.0 & 5.2 & 2451.7 & 5.9 & 2533.8 & 7.9 & 8.5 \\
\hline $\mathrm{Z5}$ & $12: 1 \mathrm{clr}$ cls sharp pr & 58 & 4.26 & 0.94 & 0.592 & 303 & 0.359738 & 0.003500 & 6.23777 & 0.12329 & 0.125760 & 0.001886 & 1980.9 & 16.6 & 2009.8 & 17.3 & 2039.5 & 26.6 & 3.3 \\
\hline Z6 & 1 brkn clr, cls pr tip & 66 & 28.93 & 2.00 & 0.195 & 909 & 0.419436 & 0.001233 & 8.88509 & 0.04855 & 0.153637 & 0.000617 & 2257.9 & 5.6 & 2326.3 & 5.0 & 2386.8 & 6.8 & 6.4 \\
\hline
\end{tabular}

Notes:

All analyzed fractions represent best optical quality (crack-, inclusion-, core-free), fresh (least altered) grains of zircon. Zircons were chemically abraded. Abbreviations: Z - zircon; clr - clear; cls - colourless; fl - flat; pr - prism/prismatic; sl - slightly; sm - small; rnd - rounded; irreg - irregular; brkn - broken.

$\mathrm{Pb}^{\top}$ is total amount (in picograms) of $\mathrm{Pb}$.

$\mathrm{Pb}_{\mathrm{C}}$ is total measured common $\mathrm{Pb}$ (in picograms) assuming the isotopic composition of laboratory blank: ${ }^{206} \mathrm{~Pb} /{ }^{204} \mathrm{~Pb}-18.221 ;{ }^{207} \mathrm{~Pb} /{ }^{204} \mathrm{~Pb}-15.612 ;{ }^{208} \mathrm{~Pb} /{ }^{204} \mathrm{~Pb}-{ }^{39} .360(\mathrm{errors}$ of $2 \%$ ). $\mathrm{Pb} / \mathrm{U}$ atomic ratios are corrected for spike, fractionation, blank, and, where necessary, initial common $\mathrm{Pb} ;{ }^{206} \mathrm{~Pb} /{ }^{204} \mathrm{~Pb}$ is corrected for spike and fractionation.

$\mathrm{Th} / \mathrm{U}$ is model value calculated from radiogenic ${ }^{208} \mathrm{~Pb} /{ }^{206} \mathrm{~Pb}$ ratio and ${ }^{207} \mathrm{~Pb} /{ }^{206} \mathrm{~Pb}$ age, assuming concordance.

Disc. (\%) - per cent discordance for the given ${ }^{207} \mathrm{~Pb} /{ }^{206} \mathrm{~Pb}$ age.

Uranium decay constants are from Jaffey et al. (1971). 


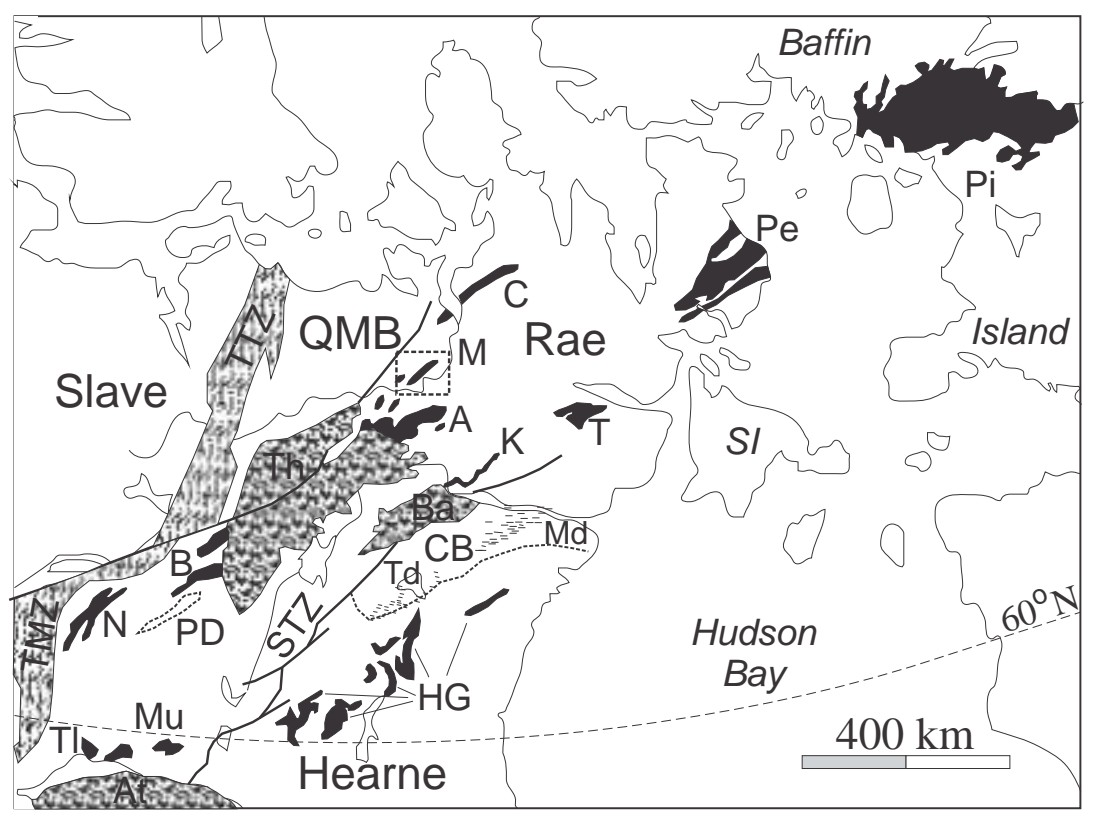




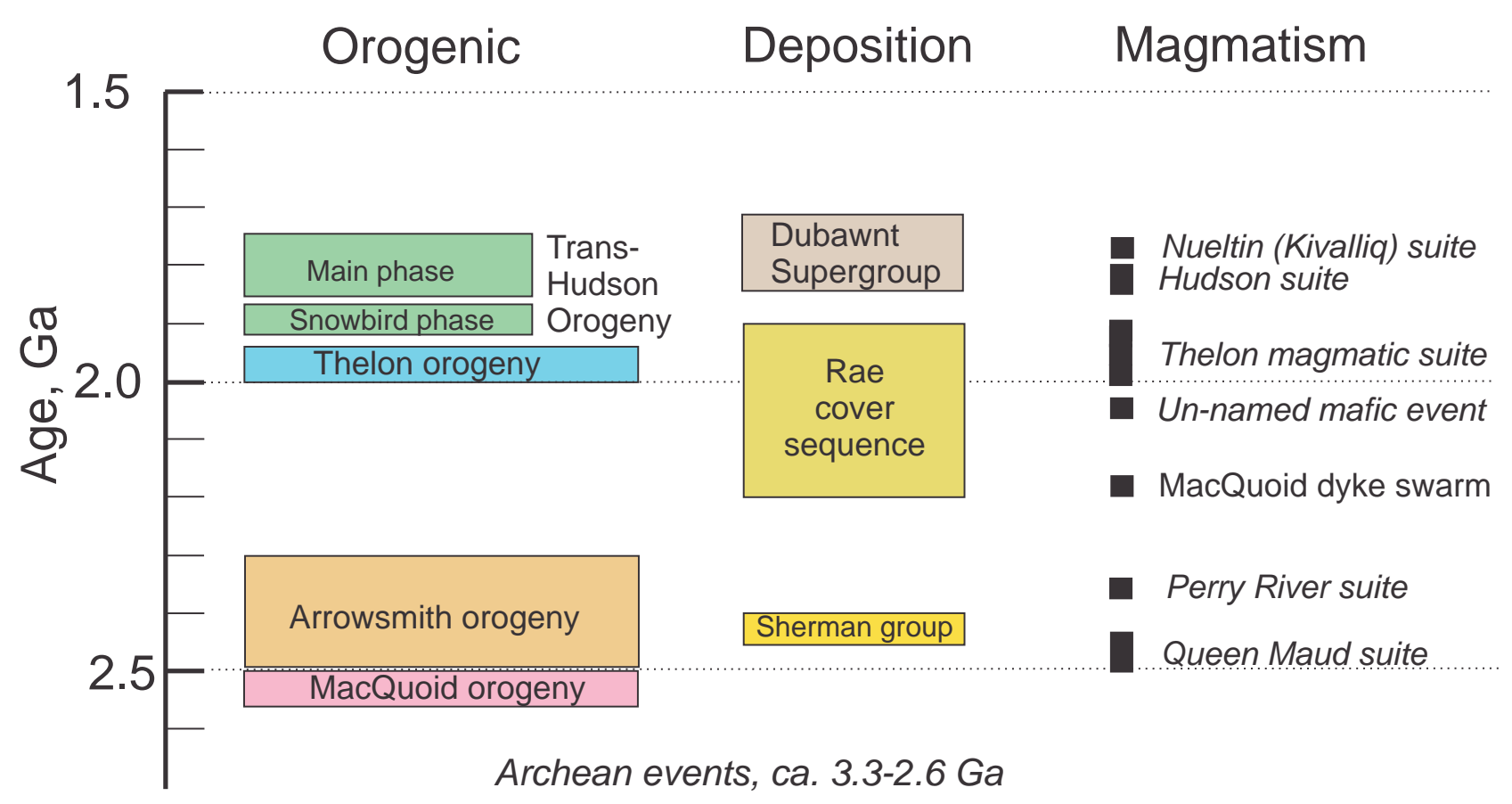

https://mc06.manuscriptcentral.com/cjes-pubs 


\section{$66^{\circ} 30^{\prime} \mathrm{N}$}

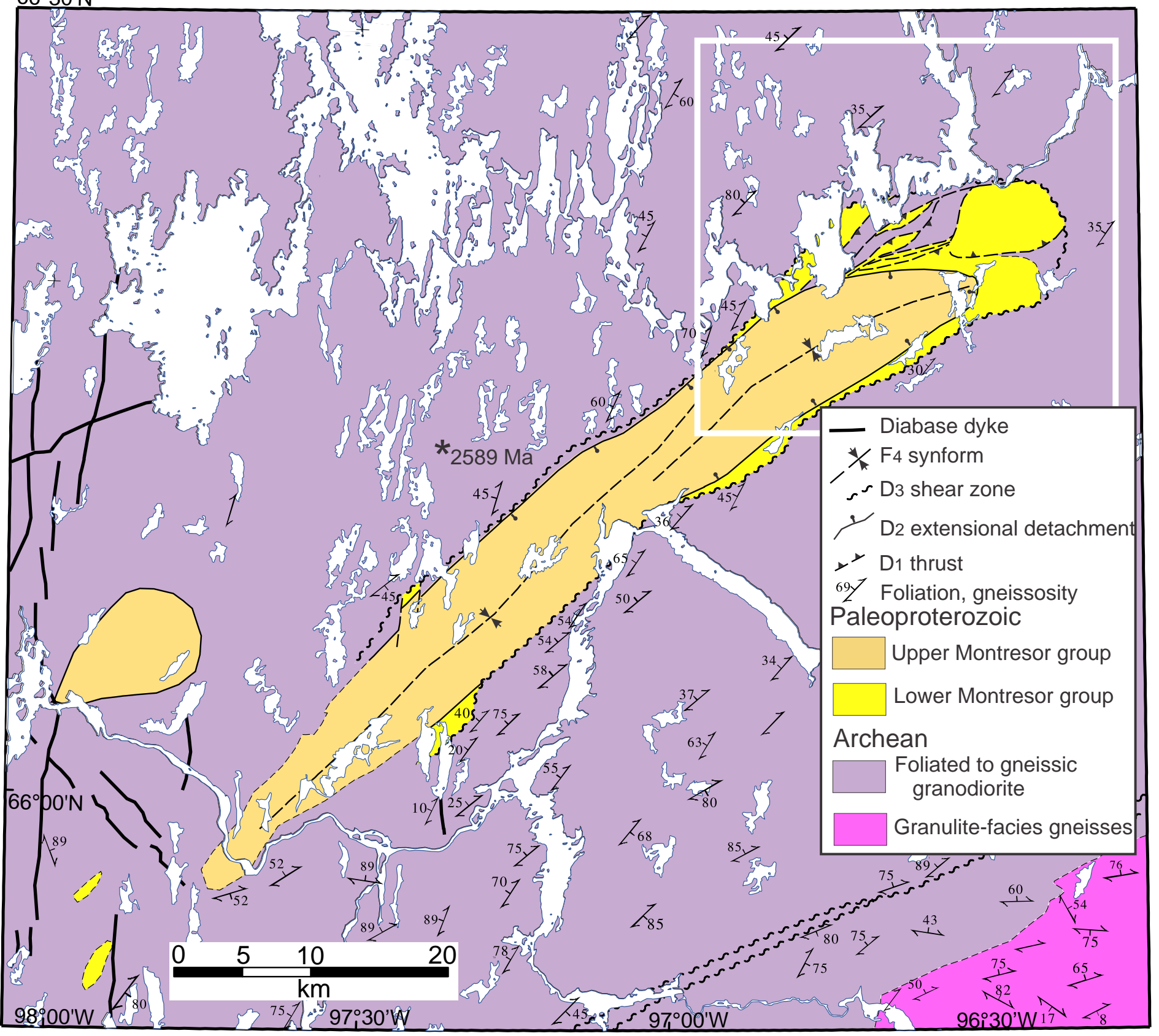




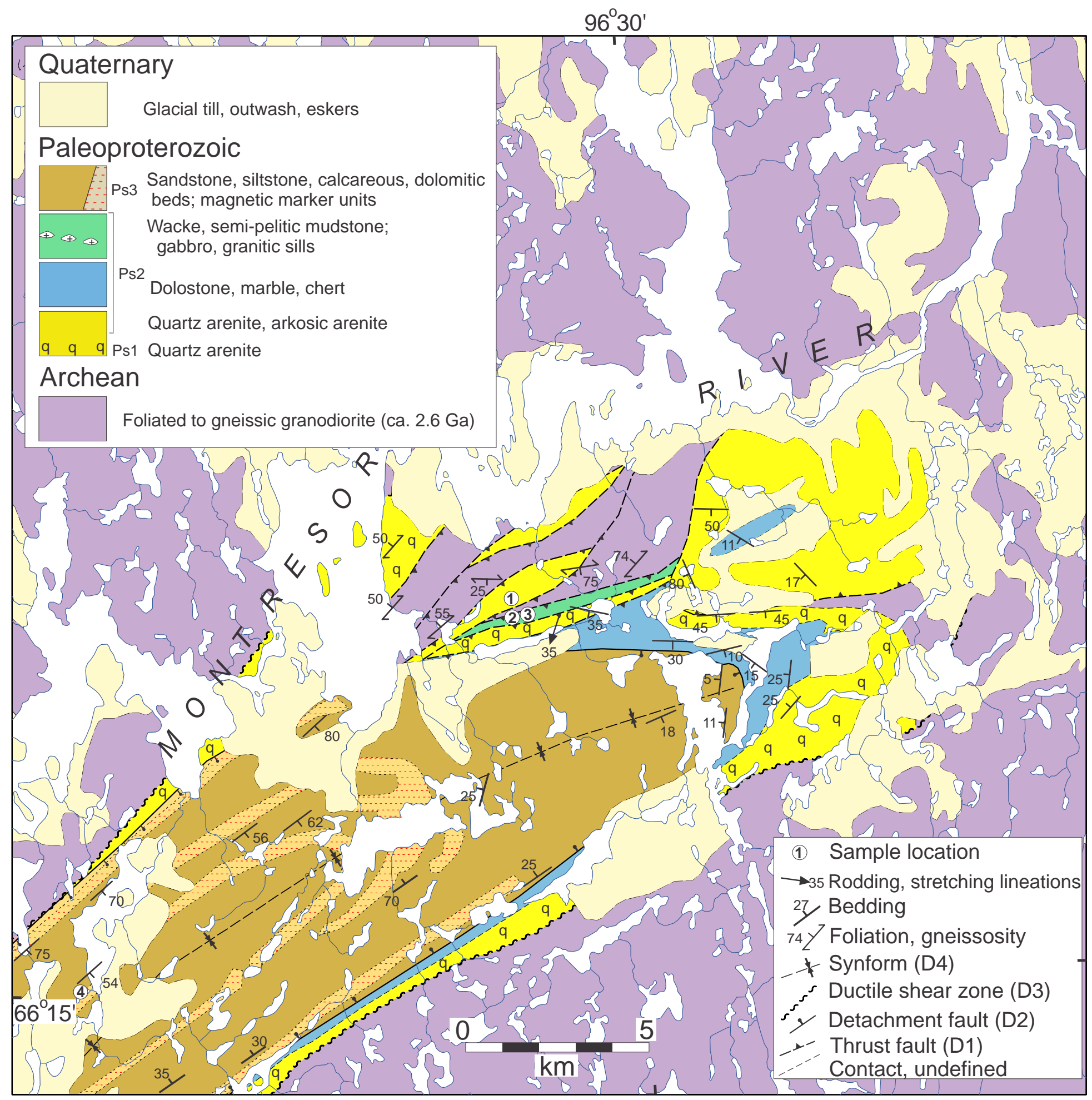



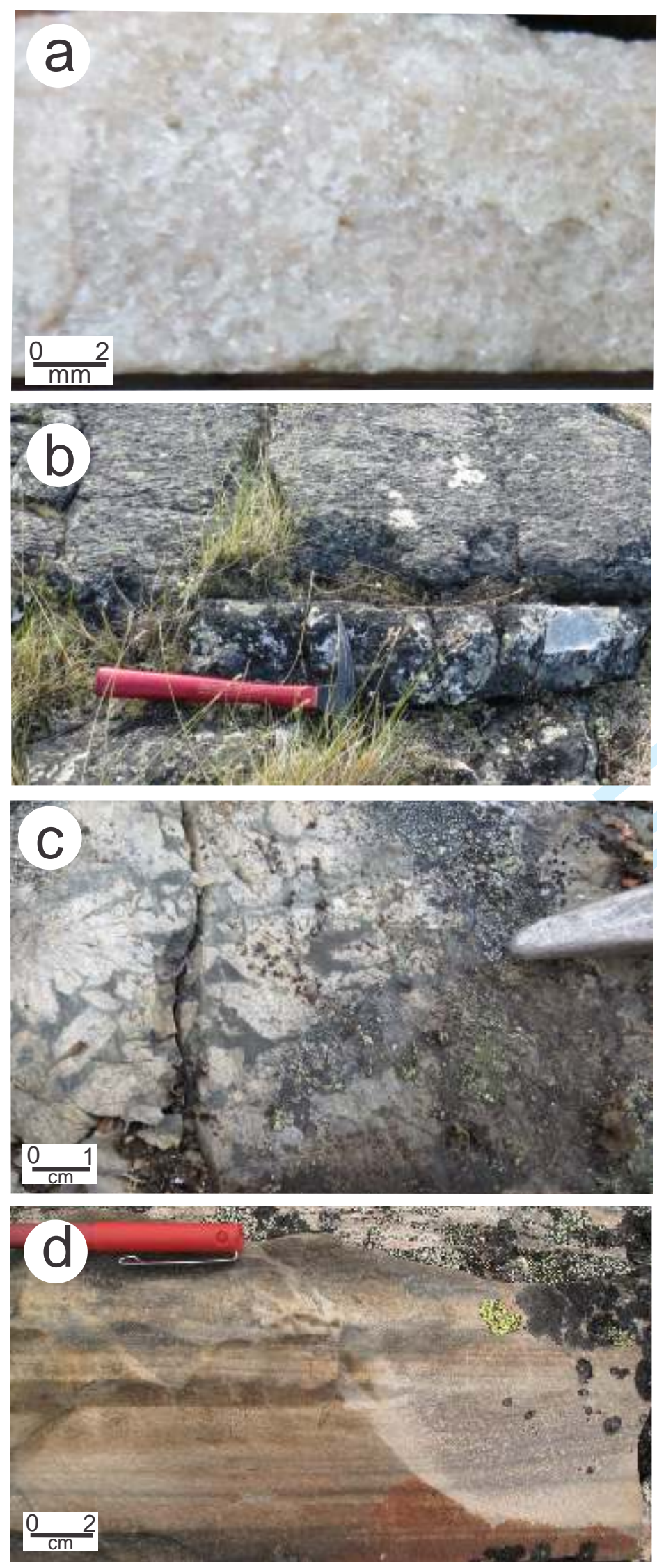

https://mc06.manuscriptcentral.com/cjes-pubs 


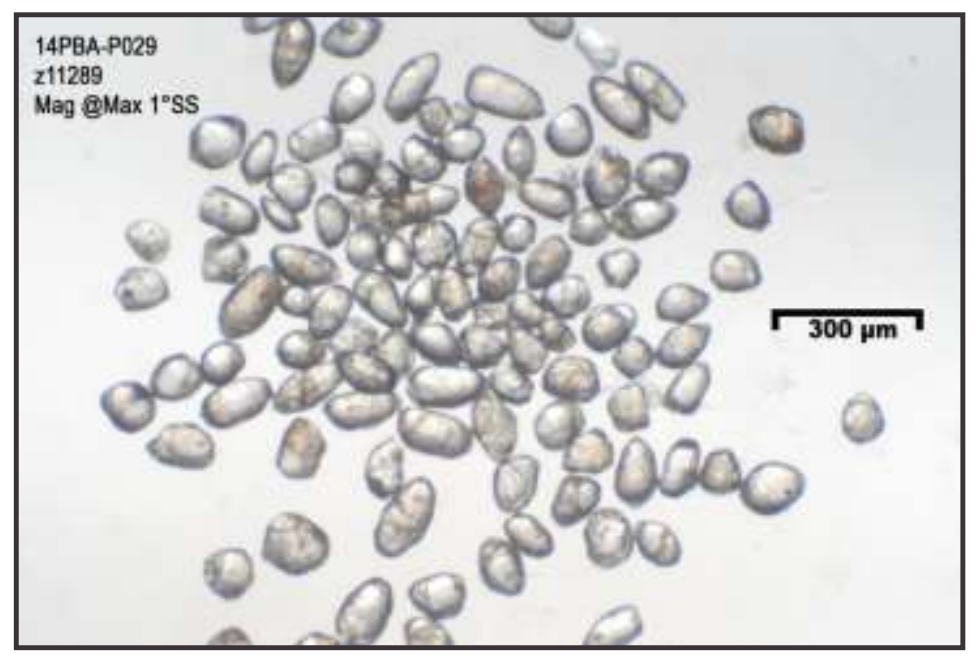

Percival et al. Fig. 6 


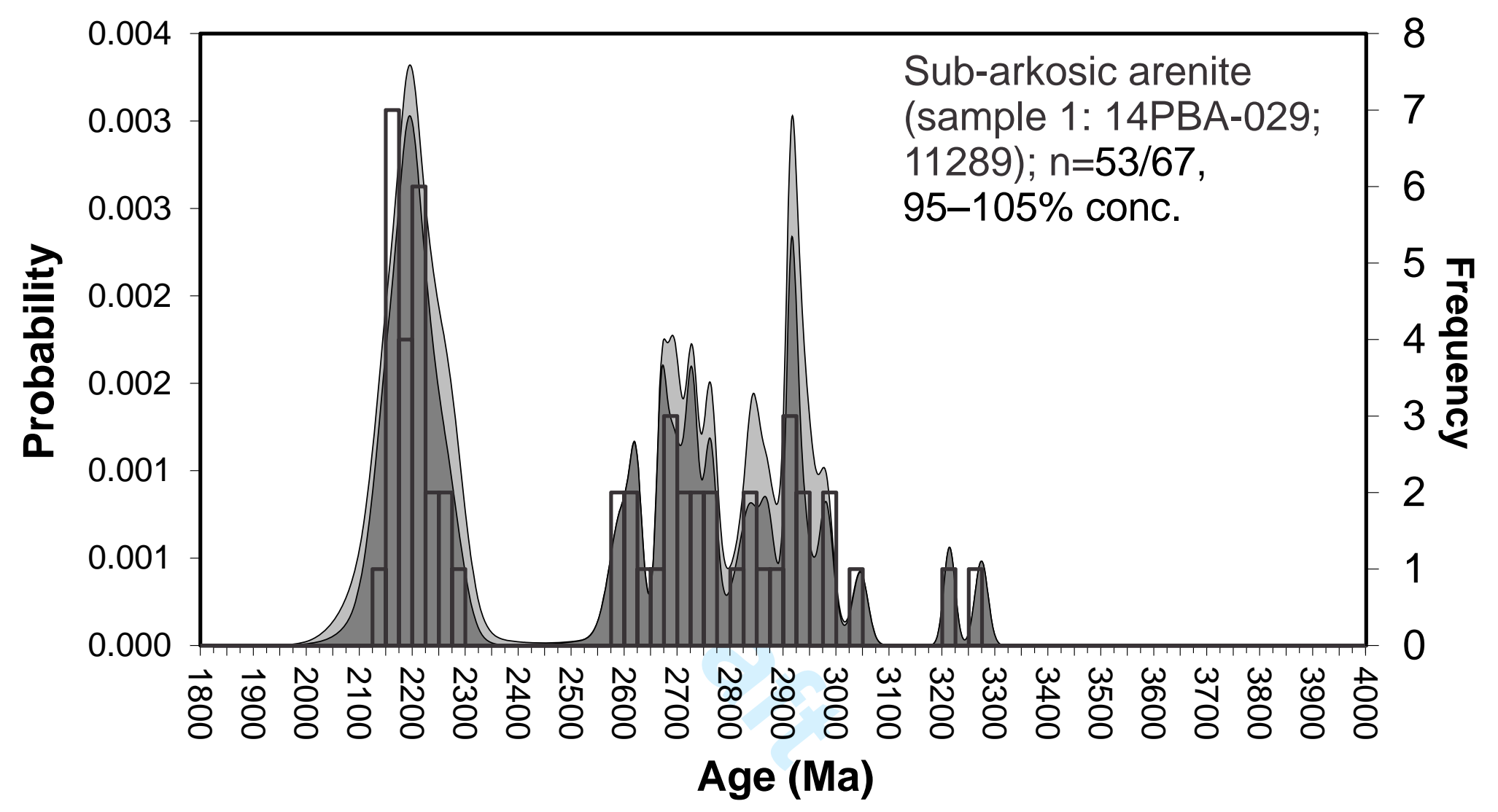




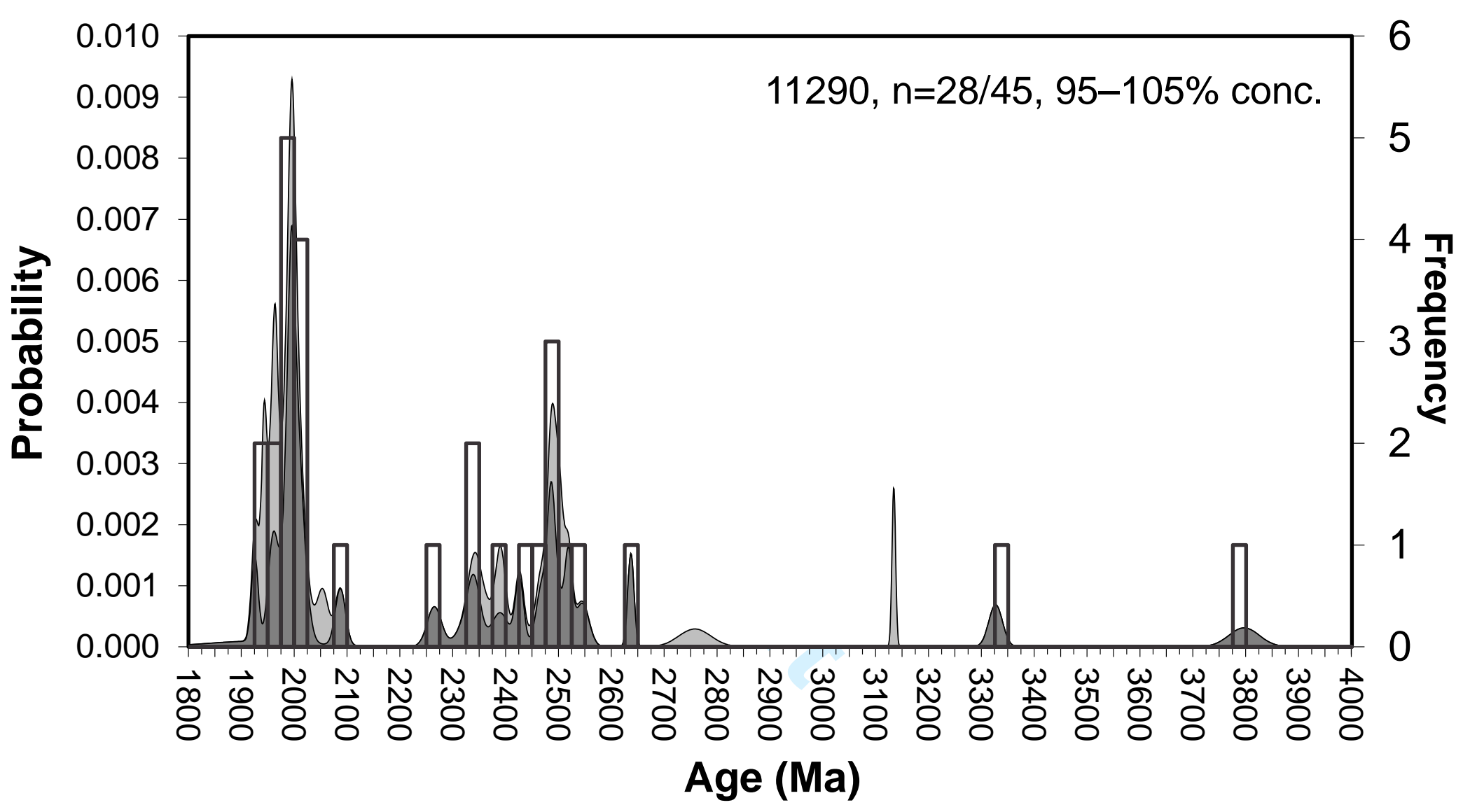




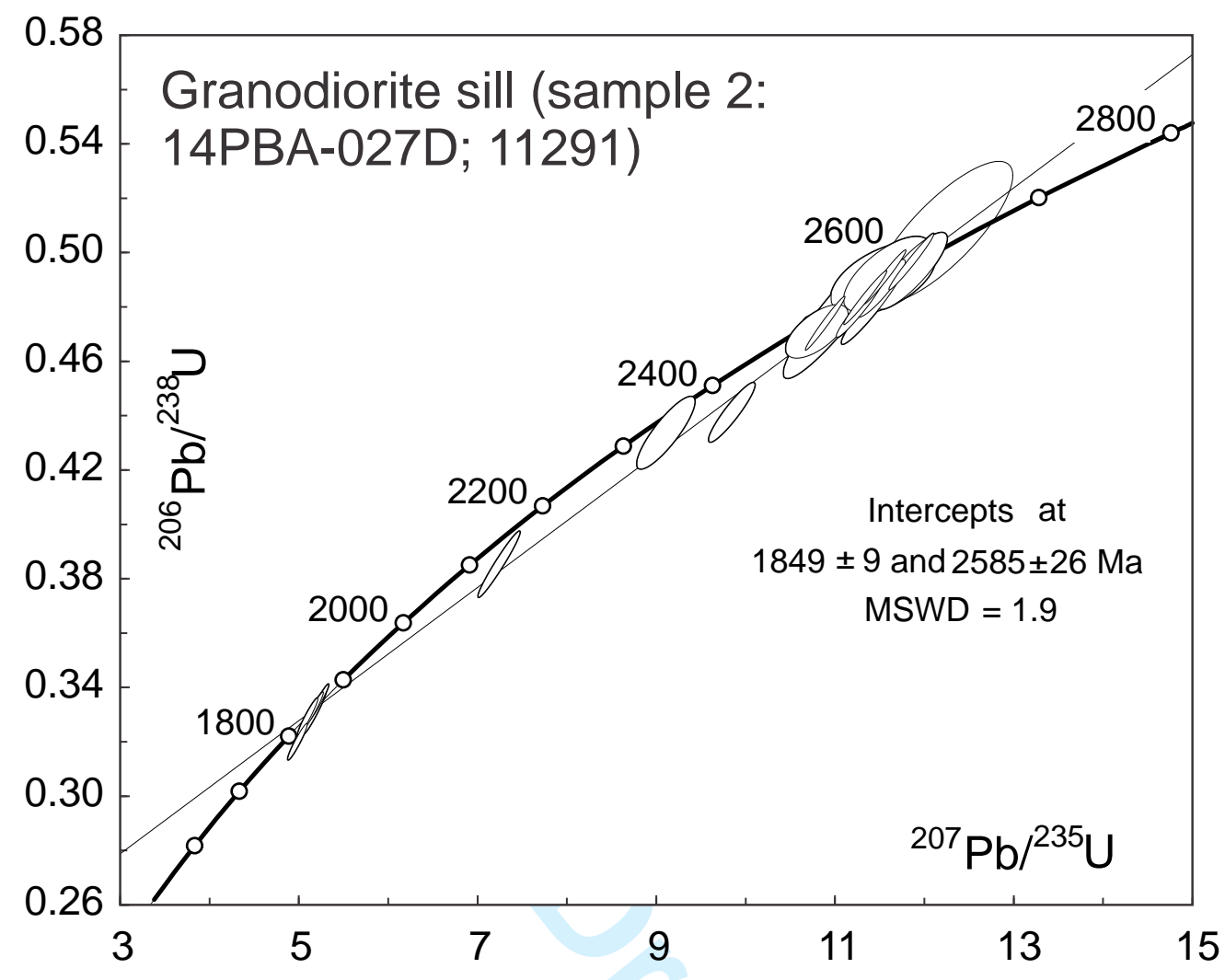




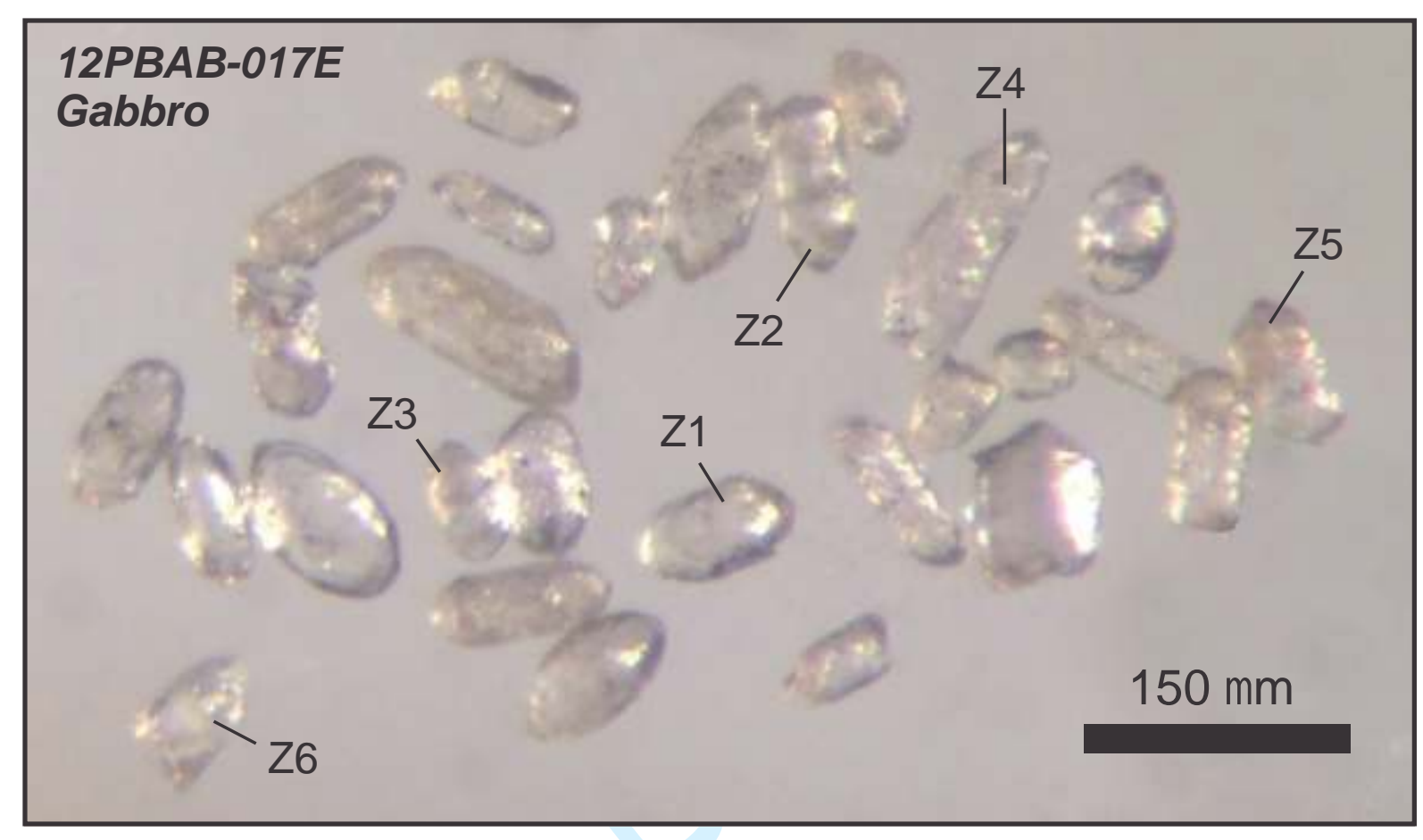

Percival et al. Fig. 9 

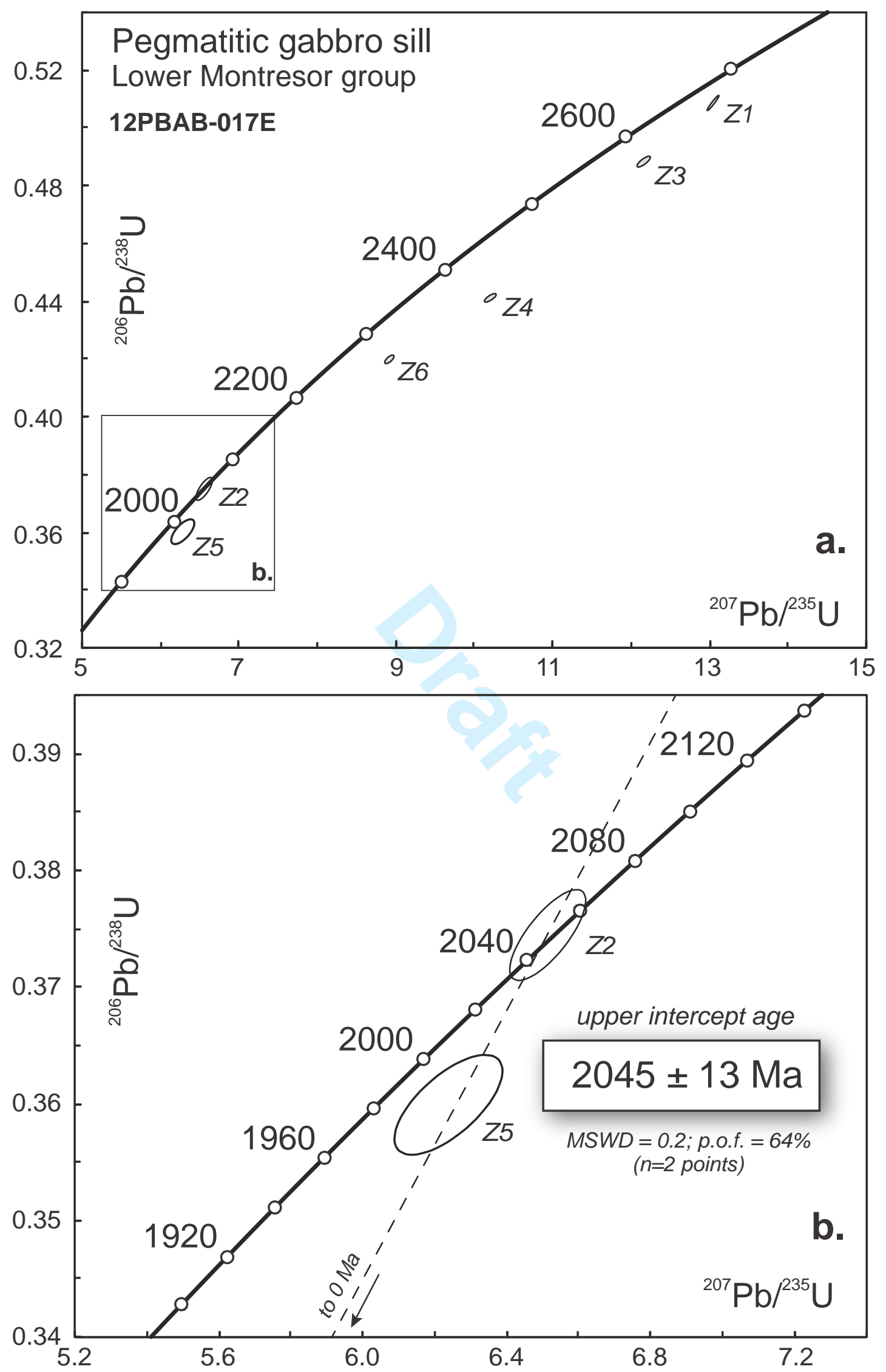

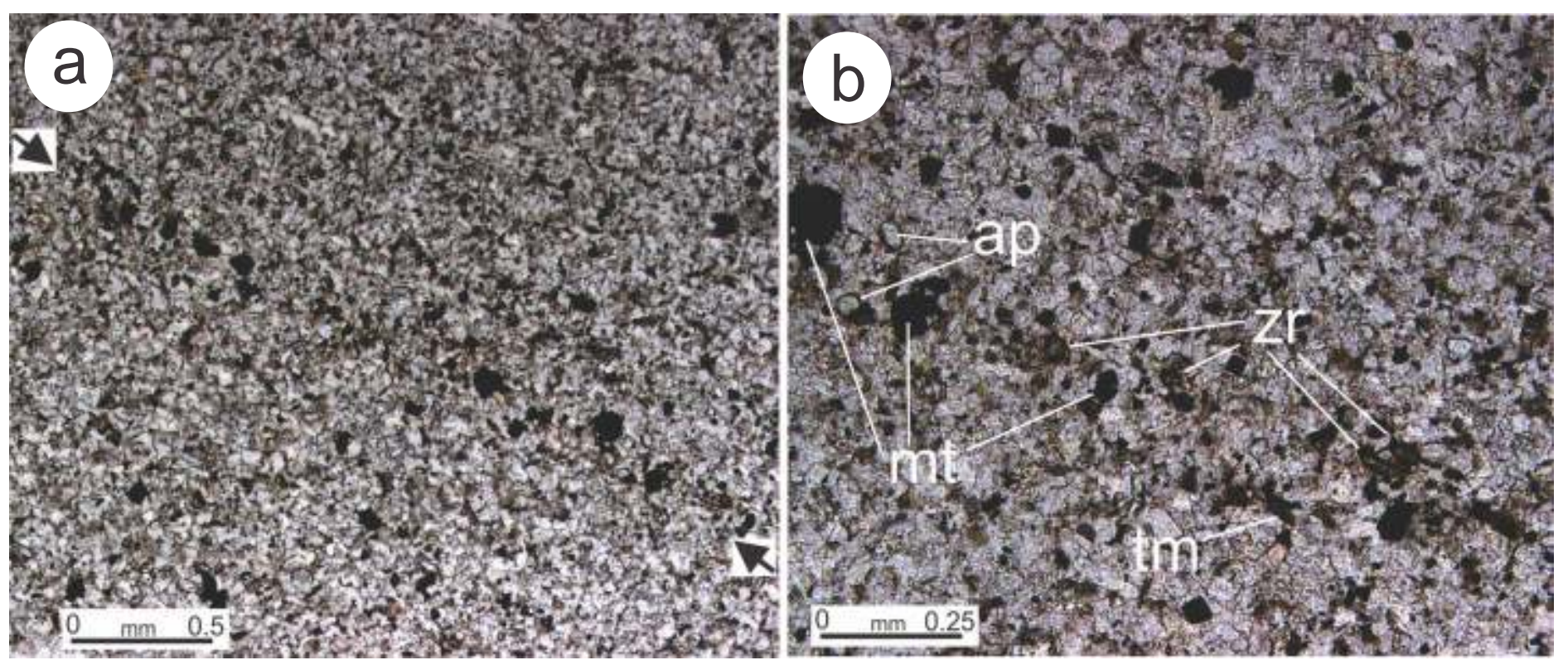

Percival et al. Fig. 11 


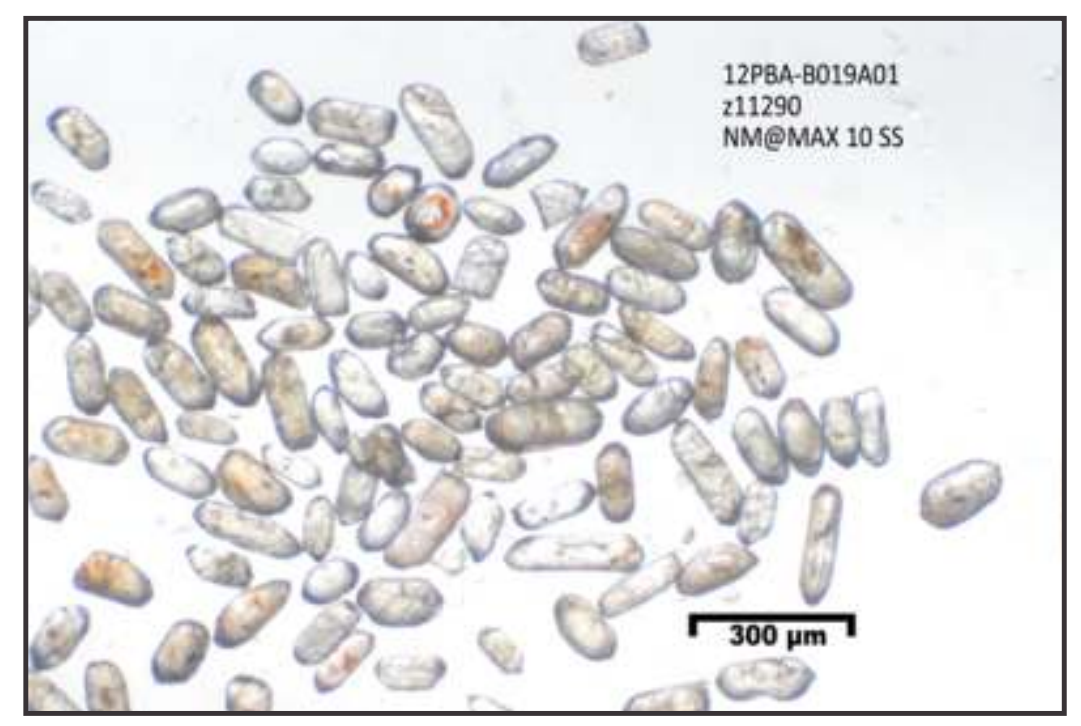

Percival et al. Fig. 12 


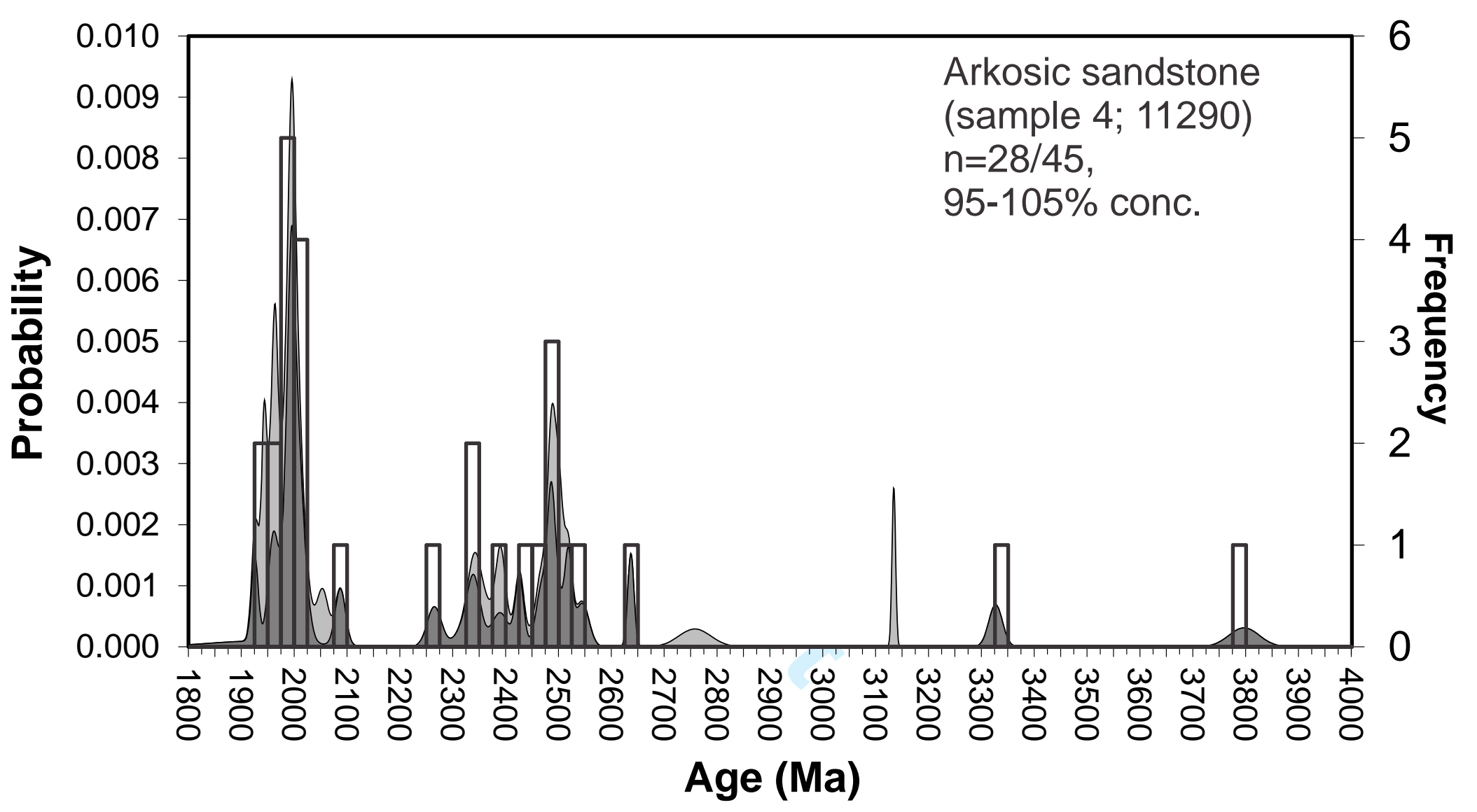




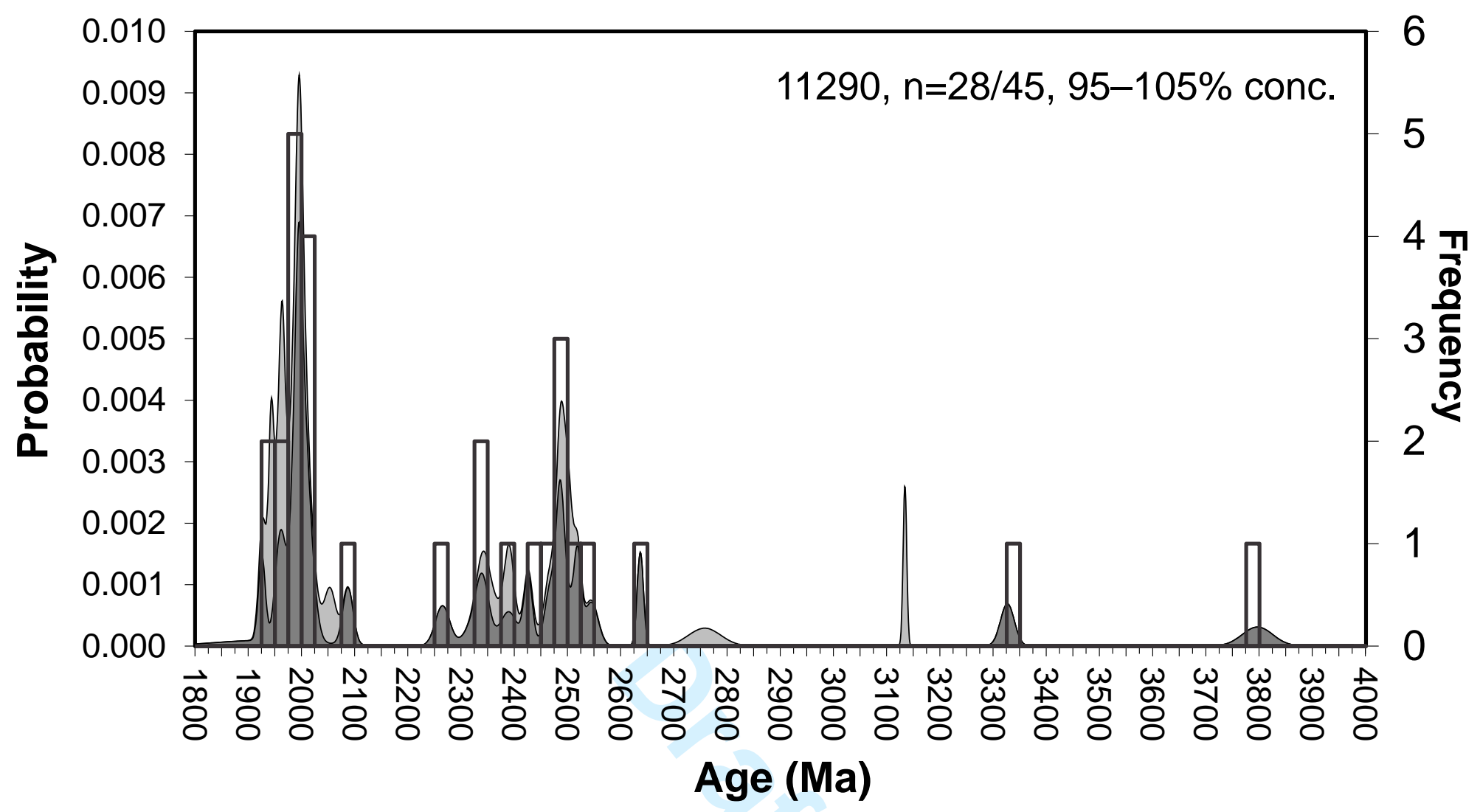

Percival et al. Fig. 11 


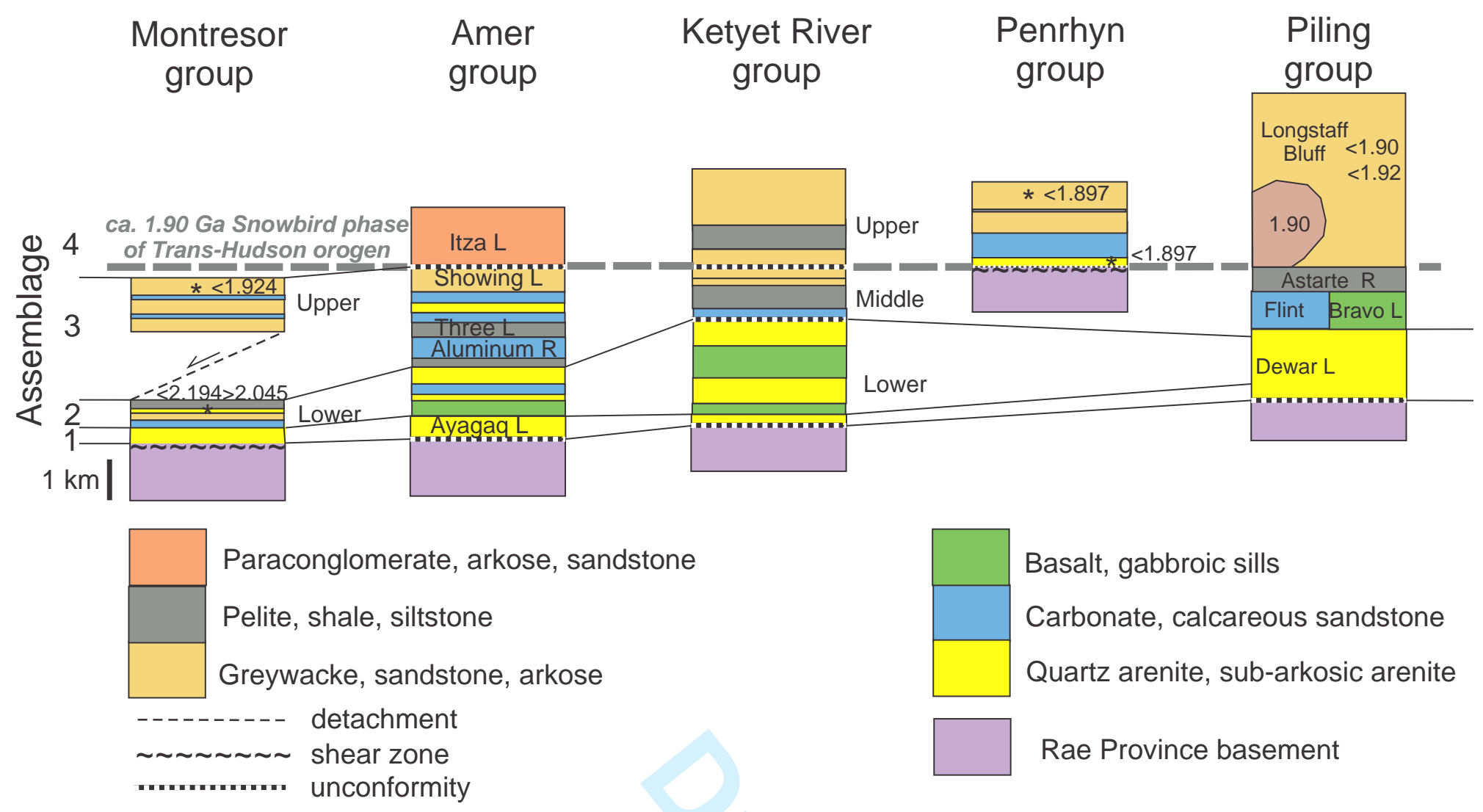

